This paper is published as:

Druckman, A. and T. Jackson (2008). "Household energy consumption in the UK: a highly geographically and socio-economically disaggregated model." Energy Policy 36(8): 3167-3182.

\title{
Household energy consumption in the UK: a highly geographically and socio-economically disaggregated model
}

\author{
A. Druckman* and Jackson, T. \\ Research Group on Lifestyles, Values and Environment (RESOLVE) \\ University of Surrey, UK
}

\begin{abstract}
Devising policies for a low carbon society requires a careful understanding of energy consumption in different types of households. In this paper we explore patterns of UK household energy use and associated carbon emissions at national level and also at high levels of socio-economic and geographical disaggregation. In particular, we examine specific neighbourhoods with contrasting levels of deprivation, and typical 'types' (segments) of UK households based on socio-economic characteristics. Results support the hypothesis that different segments have widely differing patterns of consumption. We show that household energy use and associated carbon emissions are both strongly, but not solely, related to income levels. Other factors, such as the type of dwelling, tenure, household composition and rural/urban location are also extremely important. The methodology described in this paper can be used in various ways to inform policy-making. For example, results can help in targeting energy efficiency measures; trends from time series results will form a useful basis for scenario building; and the methodology may be used to model expected outcomes of possible policy options, such as personal carbon trading or a progressive tax regime on household energy consumption.
\end{abstract}

Keywords: sustainable consumption; household energy; carbon emissions; consumer segmentation.

\section{Introduction}

In order to devise strategies to move to low carbon, sustainable lifestyles in an equitable and efficient fashion, policy-makers will need to understand the empirical links between people's lifestyles and the associated energy consumption and carbon emissions (Carbon Trust 2006; Jackson 2008; Jackson et al. 2006). They will need answers to questions such as: which particular kinds of consumption patterns and lifestyles are associated with more, and which with less energy consumption? What is the relative contribution to energy demand from different socio-economic, demographic, or geographical groups or lifestyle types? How much energy is attributable to specific functional use categories such as housing, transport, food, leisure and clothing? How have these energy demands changed over time, and what is the relative contribution to these historical trends from technology, economic structure, price, income and so on? How will the level and structure of these demands change in the future? What would be the energy and carbon implications of specific structural or volume shifts in consumer behaviours and practices? How might specific policies affect total energy demand and carbon emissions? And what will be the relative impacts of various policy options on different segments of the population?

This paper begins to address some of these questions. In particular we explore how household energy use is related to the socio-economic and demographic characteristics of households both at the UK national and at the local level. For the purposes of this paper, domestic energy consumption is defined 
as energy used within households: it excludes energy used for personal transport and energy embedded in goods and services purchased by households. The analysis uses a Local Area Resource Analysis (LARA) model, which has been developed at the University of Surrey (Druckman and Jackson 2007; Druckman et al. 2008). LARA estimates the average household resource usage and the associated emissions of small socio-economically and geographically homogenous geographical areas. The unique value of LARA is the extremely high levels of socio-economic and geographical disaggregation it achieves. LARA has previously been applied to material resources, such as food and clothing, and the associated solid waste arisings (Druckman et al. 2005; Druckman et al. 2008). This paper describes the application of LARA to household energy consumption and associated carbon dioxide emissions.

We investigate household energy use and associated carbon dioxide emissions in the UK in $2004-5^{1}$ at three different levels: (a) national UK level; (b) specific small geographical areas; and (c) "typical" types of households. The first analysis uses the national level dataset on which LARA is based to explore the relationship of domestic energy use (and associated carbon emissions) with income and with household composition. The latter two levels use results from LARA to show the differences (in terms of household energy use and associated carbon emissions) between different neighbourhoods and between different segments of the population. In the second analysis we focus on two specific small geographical areas, chosen to represent extremes of affluence and deprivation, being within the lowest and highest 1\% on the Index of Multiple Deprivation (IMD) 2004 (Office of the Deputy Prime Minister 2004). In the third analysis results from LARA are used to estimate the average domestic energy use and associated carbon emissions of "typical" households: typical households are based on the UK National Output Area Classification (OAC) that segments UK households into seven 'Supergroups' with different socio-demographic characteristics (Office for National Statistics 2005; Vickers and Rees 2007). The analyses enable us to start to answer questions such as those posed above.

The paper is organised as follows. Section 2 sets out the background for the paper by examining the factors that influence household energy demand, recent UK energy efficiency initiatives, and the conditions of the domestic energy market in the year of the study. The methodology is described in Section 3. The preparation of a national level dataset is first described (Section 3.1). The resulting dataset is used for the analysis at national level and is also used as a foundation for LARA. Section 3.2 describes the methodology used in LARA. In Section 3.3 we give an overview of the modifications that have been made to LARA for this specific application. Section 3.4 gives an overview of the Index of Multiple Deprivation and Section 3.5 provides a brief explanation of the UK National Output Area Classification (OAC). In Section 4, estimates of household energy consumption and associated carbon emissions are presented at the three distinct geographical levels described above. Section 5 describes some of the limitations of the study, improvements that could be made, and possible future work. The paper concludes (Section 6) with a discussion of the findings, and how LARA may be used to test possible future policy options.

\section{Background}

Domestic energy consumption in the UK in 2004 was responsible for approximately 30\% of total UK energy use and approximately $27 \%$ of total UK carbon dioxide emissions (HM Government 2006). This energy is used for space and water heating, cooking, lighting and electrical appliances, with approximately 53\% of household carbon emissions being due to space heating, $20 \%$ due to water heating, 22\% due to lights and appliances (HM Government 2006).

Household energy demand and associated carbon emissions depend on many factors. For example, space heating is highly dependent on technical factors such as the type of dwelling, its levels of insulation and the efficiency of the heating mechanism. It is also dependent on choice of internal temperature, the average of which has risen by about $6^{\circ} \mathrm{C}$ between 1970 and 2001 (Shorrock and Utley 2003). This rise in mean internal temperature may be partly considered to be a lifestyle choice, for example, the choice to wear just a tee-shirt with no jumper indoors on cold winter days. It may 
also be due to changes in the technical arrangements of home heating systems. For example, with the increased take-up of central heating, householders may now be more likely to maintain all rooms at one temperature rather than use heating controls to enforce temperature differentials between, say, living, sleeping and unoccupied rooms. Similarly, energy use for water heating and wet appliances, such as dishwashers and washing machines, depends on technical factors (such as the efficiency of the appliances), as well as lifestyle choices (such as the number of times clothes are worn before being washed, or the frequency of and time taken showering). Total household energy use is therefore complex to model, as it must take account of a wide variety of technical and lifestyle factors.

As is commonly known, expenditure is generally related to income (Office for National Statistics Various years). Almost every expenditure incurs use of resources and therefore resource use is also related to income (Carbon Trust 2006; Jackson et al. 2006; Jackson et al. 2007). This implies that, in general, the higher a household's income is, the higher its carbon footprint. In this paper we examine the relationship between domestic fuel use (and associated carbon emissions) with income, and compare results with those found by Dresner and Ekins (2004). Additionally we explore other factors on which domestic energy consumption and associated carbon emissions depend.

In the UK energy prices for domestic consumers are relatively low: gas prices (including taxes) are amongst the lowest in EU 15/G7, and electricity prices are below the median (DTI 2006). However, many UK households struggle to afford adequate heating for their homes. In fact there are around 2.5 million households who live in fuel poverty (BERR 2007; FPAG 2006), which is defined as a household that has to spend more than $10 \%$ of its income on energy to heat its home to an adequate standard (DTI 2006). Whether a specific household is in fuel poverty or not depends on three major factors: the energy performance of the dwelling, the cost of energy and household income (DTI 2006).

A UK Government initiative, called the Energy Efficiency Commitment (EEC), has placed an obligation on energy supply companies to reduce their customers' carbon emissions by delivering energy efficiency into customers' homes (Defra 2006; DTI 2007; HM Government 2006). A possible extension of the EEC for 2008-11 in the form of the Carbon Emission Reduction Target (CERT) has recently been announced (DTI 2007). To meet their EEC targets, suppliers can choose from a range of measures, such as installation of loft or cavity wall insulation in customers' dwellings. The EEC does not have a specific objective to reduce fuel poverty, but it requires suppliers to direct $50 \%$ of energy savings towards a priority group of low-income customers. Evaluation of the first phase of the EEC (2002-2005) suggests that the net present value (discounted over the whole lifetime of the installed measures) from reduced energy bills and increased comfort benefiting this group of priority customers was worth around £1.8 billion (DTI 2007; Lees 2006).

An alternative to a measures-based approach such as the EEC, that is being investigated by the UK government, is a cap-and-trade supplier obligation (Defra 2007b). The major differences between the two approaches are first that a cap-and-trade approach would focus suppliers efforts on their own customers. This has the ability to make households that have relatively low emissions and low incomes become of interest to suppliers, whereas under a measures-based approach these householders do not stand to benefit (Roberts et al. 2007). The second major difference is that the capand-trade approach focuses suppliers on achieving real demand or emissions reductions from their customers, and this can be achieved not only through technical installations but also through behaviour change. Reductions through behaviour change can often be more cost effective (Roberts et al. 2007) and have the potential to be achieved quickly (Jackson 2005).

Two of the major factors that effect the energy performance of a dwelling are its type (detached, semidetached or terraced house, bungalow or flat, for example) and the level of energy savings measures installed. The average heat losses of different types of dwellings range from $365 \mathrm{~W} /{ }^{\circ} \mathrm{C}$ for a detached house down to $182 \mathrm{~W} /{ }^{\circ} \mathrm{C}$ for a flat (see Table 1 ). Investment in energy efficiency measures such as loft insulation, varies with the type of tenure (Utley and Shorrock 2006). For example, in 2004, registered social landlord (RSL) dwellings had the highest proportion of dwellings (21\%) with $15 \mathrm{~cm}$ or more loft insulation ${ }^{2}$ (Utley and Shorrock 2006). The sectors with the next highest proportion of 
homes with $15 \mathrm{~cm}$ or more loft insulation are the owner occupied sectors (20\%), and local authority rented dwellings (16\%). The lowest proportion of dwellings with this depth of loft insulation are in the private rented sector, with just $9 \%$ of dwellings reaching this standard. This is because there is a mismatch in this sector between the party paying the costs of installing energy efficiency measures (the landlord) and the party receiving the benefits (the tenant) (Oxera 2006; Wilkinson and Goodacre 2002). This is a type of market failure, and is known as the 'tenant-landlord problem' (Jackson 1992; RCEP 2000) and is the reason why dwellings in this sector have, on average, relatively low thermal insulation.

From the above discussion it can be seen that analysis of the energy consumption of households should take account of type of dwelling and tenure as well as income. The Local Area Resource Analysis (LARA) model described in this paper categorises households according to tenure and type of dwelling, as well as the age and economic status of the head of the household, which are used as proxies for income. Further details may be found in Druckman and Jackson (2007).

The year of the study reported in this paper is 2004-05. This covers a period of high increases in retail price of fuels in the domestic sector. For example, the price of domestic gas ${ }^{3}$ rose by, on average, $16.0 \%$ between the first quarter of 2003 and the first quarter of 2005, and that for electricity rose by $10.6 \%$ over the same period (DTI 2005). The UK domestic energy market has been changing since market liberalisation in 1998. Traditionally, households were supplied by their local energy suppliers (known as their "home" supplier), but now, however, customers have started to move away from their home suppliers. By the end of March 2005 43\% of electricity consumers and the same percentage of gas consumers had moved away from their home suppliers (DTI 2005). Nevertheless, this leaves over $50 \%$ of consumers still with their home suppliers, and energy prices, even under the liberalised market regime, still have significant variation on a regional basis. Furthermore, a variety of methods of payment are available to domestic consumers, and these attract different tariffs. For both gas and electricity, customers paying by direct debit pay less than customers on other tariffs (DTI 2005). Thus the price structure for domestic fuels in 2004-05 was unstable, complex and fragmented.

When looking at carbon emissions due to domestic energy use another important factor is the size of households. The number of households in Great Britain was 24.2 million in 2006, having increased by 30\% between 1971 and 2006 (Office for National Statistics 2007). This compares with a population increase of just $8 \%$ over the same period, with the average household size decreasing from 2.9 persons to 2.4 persons over the period. According to the Office for National Statistics (2007: p14) "Reasons for this decrease include more lone-parent families, smaller family sizes, and an increase in one-person households, although the rise in one-person households has levelled off since 1991". It is predicted that these trends will continue and that the number of households will rise to 28.7 million in 2021, with an average household size of 2.1 by that date (Department of Communities and Local Government 2007). In this paper we investigate the economies of scale that are achieved by larger households, to draw some conclusions concerning the impact that the increased number of smaller households may have on future domestic energy use and associated carbon dioxide emissions.

\section{Methodology}

We first describe preparation of the national level dataset which is used for analysis on a national level, as reported in Section 4.1, and is also being used by the Centre for Sustainable Energy ${ }^{4}$ as a basis for investigating various policy options (Roberts et al. 2007; Thumin et al. 2007). The national level dataset is also used as a basis for LARA, the methodology for which is described in Sections 3.2 and 3.3. 


\subsection{National level}

Preparation of the national level dataset involves three steps: (1) household expenditure on each type of fuel is taken from the Expenditure and Food Survey (EFS); (2) household expenditure is converted to quantity of energy used, using price information for each type of fuel; (3) carbon dioxide emissions are estimated by using carbon emissions factors for each type of fuel.

Analysis of the resulting dataset, which includes household income data, is used to explore the relationships of domestic energy use (and associated carbon emissions) with income and with household composition. It is also used to estimate how household energy use and associated carbon emissions vary across Government Office Regions. This is used to estimate regional weighting factors for use in estimating results for specific case study areas. The national level dataset is also used to investigate the relationship between household energy use (and associated carbon emissions) with household composition: to further this specific objective, pre capita values are estimated.

Each of the steps outlined above is now explained in more detail.

\subsubsection{Household expenditure on fuel}

Data from the UK Expenditure and Food Survey (EFS) is used as a basis for this study (Office for National Statistics and Department for Environment Food and Rural Affairs 2004-2005). This dataset gives information concerning each of the approximately 7,000 sampled households (called 'case households' from now on). It gives details of the expenditure of each case household on fuel by the various payment methods shown in Table 2. It also gives information on the socio-economic and demographic characteristics of each household, and the month when the sample was taken.

\subsubsection{Estimation of energy use}

As described in Section 2, fuel prices vary regionally and there were also significant price rises during the year of study (2004-05). Furthermore, prices also vary depending on the type of payment method used (Table 2). In order to reflect these variations a matrix of energy prices was developed by the Centre for Sustainable Energy (CSE) ${ }^{5}$. The matrix of prices gives the price paid for each type of fuel for each Government Office Region, for each payment method and for different time bands (AprilJuly 04; August-December 04; January-March 05). The prices are based on data from $\mathrm{DTI}^{6}$, Sutherland (SALKENT) Tables, ${ }^{7}$ EnergyWatch ${ }^{8}$ and BRE ${ }^{9}$. Further details concerning the methodology used in compiling this price matrix is given in Preston (2007).

Estimates of energy consumption for each type of fuel for every case household are in the first instance calculated by dividing expenditure by the appropriate price. An adjustment to this is required as, in essence, this study uses a sample of approximately 7,000 households to estimate total fuel demand in the UK, and these households may not be representative of UK households in terms of energy use. Additionally, various inaccuracies in the price matrices and matching them to energy consumption may also contribute to the potential disparities (see Section 5 for more details). Therefore an adjustment is carried out to ensure that total energy use in this study corresponds with published national delivered energy totals for each fuel type. In this adjustment, first an initial estimate of mean UK energy consumption is calculated, and then total UK consumption for each type of fuel is estimated by scaling up by the number of households in the $\mathrm{UK}^{10}$. These totals are compared to the UK delivered fuel totals published in Energy Trends (DTI various years) and in the Digest of United Kingdom Energy Statistics (DUKES) (Department of Trade and Industry various years), and the estimates are adjusted accordingly.

\subsubsection{Estimation of carbon emissions}

The carbon emissions factors used to estimate the amount of carbon dioxide emitted due to use of each type of fuel are shown in Table 2. Again an adjustment is required, as inaccuracies arise in emissions estimated due to Other Fuel use ${ }^{11}$, mainly due to the small number of household cases in the EFS that purchase Other Fuels. The adjustment procedure is carried out by estimating total carbon 
emissions for the UK on the lines explained above, and then adjusting the carbon due to Other Fuels accordingly.

\subsection{Local Area Resource Analysis (LARA) methodology}

The above steps of data preparation yield a rich dataset at a national level, but do not give any information on the energy use and carbon emissions of small local areas. This is because the EFS is an annual national survey of approximately 7,000 households, and the sample size is not large enough to give information at local area level directly. Therefore, in order to obtain information at local area level, an indirect approach is adopted in which data from the EFS is combined with an auxiliary dataset. This is a typical example of a small area estimation problem (Chambers and Chandra 2006; Heady et al. 2003; Rao 2003) and the methodology adopted in LARA may be described as a 'conditional mean value replacement' approach. The auxiliary dataset is the UK Census 2001 (Office for National Statistics 2001).

LARA estimates the household resource usage and associated carbon emissions of small local areas, and, for the purposes of this study, local areas are based on Output Areas (OAs) as defined in the UK 2001 Census (Office for National Statistics 2006). Use of OAs gives the highest level of geographical detail available from Census 2001. OAs are small areas of approximately 124 households on average, that are as socially homogeneous as possible, based on tenure of household and dwelling type. LARA uses the Census 2001 definition of a household unit, which defines a household as "one person living alone, or, a group of people living at the same address with common housekeeping - that is, sharing either a living room or at least one meal a day" (Office for National Statistics 2001).

A system diagram of LARA, as used in this application, is shown in Figure 1. Modifications have been made to the previous version of LARA in order to take account of the fragmented and unstable nature of domestic fuel prices in 2004-05. These modifications are described in Section 3.3.

A high level over-view of LARA's methodology is as follows: socio-economic and demographic characteristics of households in each local area are found from the Census. This is held in the Local Area Characteristics database. The mean energy use and associated carbon emissions of households with matching socio-economic characteristics is held in the Household Energy Database. From this the average household energy use and emissions of each local area is determined. A more detailed explanation will now be given.

Households in each OA are classified into Household Categories (HoCs). Table 3 shows how each of the 45 HoCs (labelled A-AS) is uniquely described by type of dwelling, tenure, and the age and economic status of the Household representative (HRP) ${ }^{12}$. The proportion $p_{i}$ of households in a local area that belong to each $\mathrm{HoC} i$ is found from Census 2001. This information is held in the Local Area Characteristics Database (Figure 1). For more details the reader is referred to Druckman et al (2008) and Druckman and Jackson (2007).

Expenditure data on fuel use are obtained from the Expenditure and Food Survey (EFS) ${ }^{13}$, and converted to energy use and carbon dioxide emissions as explained in Section 3.1.1-3.1.3 ${ }^{14}$. The EFS includes socio-economic and demographic data for each case household (Office for National Statistics Various years). By classifying each case household in the EFS into its appropriate HoC, average fuel use $\left(\mathrm{f}_{i}\right)$, and associated carbon dioxide emissions $\left(c_{i}\right)$, of each HoC are estimated. This is held in the Household Energy Database (Figure 1).

Average household fuel use $\mathrm{F}^{\mathrm{kl}}$ of fuel type $k$ in local area $l$ is found by summing the average annual energy use $f_{i}^{k}$ of fuel type $k$ by households in HoC $i$ (from the Household Energy Database) weighted by the proportion $p_{i}^{l}$ of households in local area $l$ that are members of HOC $i$ (from the Local Area Characteristics Database). This can be written as: 


$$
F^{k l}=\sum_{i=1}^{i=N} p_{i}^{l} f_{i}^{k}
$$

where

$F^{k l}=$ average annual household fuel use of fuel type $k$ in local area $l$,

$p_{i}^{l}=$ proportion of households in local area $l$, that are members of HoC $i$

$f_{i}^{k}=$ average annual household fuel use of fuel type $k$, by households in HoC $i$

$i=$ HoC number, such that $i=1$ to $\mathrm{N}$, where $\mathrm{N}=$ total number of HoCs $(\mathrm{N}=45)$

A similar procedure is followed to estimate average household energy use $C^{\mathrm{kl}}$ of fuel type $k$ in local area $l$.

LARA is used to estimate the fuel use and associated emissions for every Output Area in the England and Wales. The results from LARA are reported in two ways in this paper: (a) estimated energy use and associated emissions are reported for two specific Output Areas; (b) averages for each OAC Supergroup are reported (see Section 3.5).

\subsection{Modification of LARA for energy use in a price varying market}

LARA has previously been used to estimate resource use and solid waste arisings (see for example Druckman et al (2008)). The methodology used for LARA previously was based on the assumptions that (a) prices of consumer goods can be assumed to apply nationally and that regional variations are not significant; (b) prices are constant throughout each sample year. As has been described above, these assumptions do not hold for household energy use in 2004-05 and therefore modifications were made to LARA's methodology. The data preparation steps described in Sections 3.1.1 to 3.1.3 have been added to take account of regional price variations and price rises. In the previous version of LARA equation (1) was calculated in terms of expenditure. Thus instead of holding energy and emissions data in a Household Energy Database, expenditure data was held in a Household Expenditure Database. In the previous version of LARA expenditure on a wide variety of goods was generated at Output Area level. This was converted into mass of goods and solid waste arisings for each local area (Druckman et al. 2008).

\subsection{Specific Output Areas representing contrasting levels of deprivation}

In order to illustrate LARA's ability to estimate resource use and associated emissions for specific small geographical areas, results for two specific Output Areas are shown. Regional weighting (estimated using the national level dataset, see Section 3.1) is applied to the energy consumption and associated emissions estimated by LARA for the specific case study areas, to take account of regional variations. The regional weights are reported in Appendix 1. For illustration purposes, the two Output Areas are chosen to be within the lowest and highest $1 \%$ on the Index of Multiple Deprivation (IMD). The IMD is a weighted aggregation of seven domains of deprivation: Income deprivation, Employment deprivation, Health deprivation and disability, Education, skills and training deprivation, Barriers to Housing and Services, Living environment deprivation and Crime (Office of the Deputy Prime Minister 2005).

\subsection{Analysis of "typical" households using the UK National Output Area Classification (OAC)}

In this study LARA is used to estimate the mean energy use and associated carbon dioxide emissions of households in each of the 175,434 Output Areas in England and Wales. In order to interpret results, the UK National Output Area Classification (OAC) segmentation system is used. OAC classifies Census Output Areas into 7 Supergroups, 21 Groups and 52 Subgroups based on cluster analysis. The cluster analysis is based on 41 variables chosen to represent the main dimensions of the Census 2001 
data with the minimum number of variables. A full description of OAC can be found in Vickers et al (2005), Vickers and Rees (2007) and Office for National Statistics (2005). Appendix 2 summarises the characteristics of the seven OAC Supergroups (Office for National Statistics 2005; Vickers and Rees 2007).

Although many other segmentation systems exist that may be considered 'richer' in that they capture 'lifestyle' factors, these systems are generally commercial and full details are not disclosed. For example MOSAIC UK is a geo-demographic lifestyle model that has 11 super-groups and 61 groups and 243 sub-groups (Experian 2003). The segmentation modelling is carried out using cluster analysis on 400 data variables which are weighted "depending on how well they discriminate at differing levels of geography" (Experian 2003: page 4). 54\% of the variables used are derived from Census 2001 and the remaining variables are taken from datasets such as the Electoral Roll, Consumer Credit Activity, and the Shareholders' Register. Importantly, one of the variables that is included in MOSAIC is the age of dwelling. Although many older dwellings have had energy efficiency improvements installed there still remains a close correlation between age of property and its energy efficiency (Department for Communities and Local Government 2006). From this perspective, MOSAIC offers a slight advantage over OAC. However, information from the datasets listed above is augmented with information from Experian's own lifestyle database which is based on surveys of, for example, type of newspaper readership, and computer ownership. In selecting a segmentation system to be used in this research project, it was felt that, although segmentation systems such as MOSAIC are undoubtedly successful for purposes of market research and have some advantages over OAC, OAC was considered a better choice due to its superior transparency and robustness.

\section{Results and discussions}

In this paper we report results at three different levels. First, using the national level dataset, we explore the relationship of domestic energy consumption (and associated carbon emissions) with income and with household composition. The second two levels use results estimated using LARA. We look at domestic energy consumption and associated carbon emissions in two specific case study Output Areas, chosen to represent extremes of affluence and deprivation. Finally we look at mean domestic energy consumption and carbon dioxide emissions for households in the seven OAC Supergroups.

\subsection{National level results}

The national level data reveal a positive correlation between disposable income and both energy use and associated carbon emissions ( $r=0.27 ; p<0.01$ for both). The correlation is marginally stronger for electricity $(r=0.25 ; p<0.01)$ than for gas $(r=0.23 ; p<0.01)^{15}$. These correlations are reflected in Figures 2a and b. Figure 2a shows mean household energy use by disposable income decile. It shows that the poorest $10 \%$ of households use, on average, only $43 \%$ of the energy used by the richest $10 \%$ of households. Mean carbon dioxide emissions due to household energy use show the same pattern as energy use (see Figure 2b), although the differences between the poorest and richest disposable income deciles are slightly less than for energy use, reflecting the higher carbon intensity of electricity compared to gas. The poorest $10 \%$ produce, on average, $45 \%$ of the carbon dioxide generated by the richest $10 \%$.

Dresner and Ekins (2004) carried out a similar analysis using data from the 1996 English House Condition Survey (EHCS) and the 1999-2000 Family Expenditure Survey (FES). Using income (rather than disposable income as used in this study), they found a correlation of 0.171 between energy use and household income from the EHCS and 0.207 using the FES. The differences between their results and those found in the study reported in this paper may be partially attributable to the difference between use of disposable income versus income, as we would expect a higher correlation between energy use and disposable income. It may also indicate a trend of increasing correlation between incomes and energy use with time that may be worthy of further investigation, although 
outside the remit of the current paper. Using the 1996 EHCS, Dresner and Ekins estimated the correlation between carbon dioxide emissions and income to be the same as that between energy use and income, and this result is found again in the current study. Dresner and Ekins (2004) were surprised by this result, as they had predicted that, as poorer households are less likely to use gas for heating, and gas is less carbon intensive than electricity, lower income deciles' carbon emissions should be relatively higher than their energy consumption. They reasoned that this was not, in fact, the case, because relative electricity consumption tends to increase with income, and the findings in the current research support this argument.

Figure 3 shows household expenditure on energy as a percentage of household disposable income for each disposable income decile. This clearly illustrates the highly regressive nature of energy use, with the poorest $10 \%$ of households spending nearly eight times the proportion of their disposable income as the richest $10 \%$.

Household composition is, as expected, another significant factor in domestic energy use and associated carbon emissions. Both energy use and carbon emissions are positively correlated with the number of people per household (energy use $r=0.24, p<0.01$; carbon emissions $r=0.26, p<0.01$ ). The correlation for electricity use tends to be stronger $(r=0.27, p<0.01)$ than that for gas $(r=0.20, p<0.01)$. The weaker correlation for gas reflects that gas is predominantly used for heating, and its usage is strongly influenced by factors such as type of dwelling and its energy performance. If we consider the correlation between per capita energy use and size of household we find that per capita energy use and carbon emissions are negatively correlated to household size (energy use $r=-0.33, p<0.01$; carbon emissions $r=-0.36, p<0.01$ ). This shows that a household with more people sharing is, generally, more efficient in terms of per capita energy use, and demonstrates the economies of scale that are achieved by a larger household. Again, as expected, the correlations for per capita electricity use tend to be stronger than those for gas (see Appendix 4 for results).

Further investigation into the relationship between energy use and household composition is beyond the scope of this paper, but the results shown here demonstrate that economies of scale are an important factor in household energy use and associated carbon emissions, and present an interesting area for further research. If forecasts that the number of people per household will fall in future turn out to be correct (see Section 2), then the economies of scale of larger households may be lost, and this may be a driver of increasing per capita household carbon emissions in future years.

\subsection{Specific Output Areas representing extremes of deprivation}

In this section the estimated energy consumption and associated carbon dioxide emissions are reported for two specific Output Areas that are within the lowest and highest 1\% on the IMD. The first area is highly deprived. It is in Manchester in the North West (Output Area code 00BNFK0004; postcode M4 7JD). The area is a member of the Constrained by Circumstances OAC Supergroup. It is predominantly composed of terraced housing (72\%) with $15 \%$ semi-detached houses, $10 \%$ purpose built flats and 3\% detached houses ${ }^{16}$. The second area is in Uckfield in the South East (Output Area Code 21UHHX0002; postcode TN22 5NE). The area is a member of Prospering Suburbs OAC Supergroup. It is dominated by detached houses. Maps of the two areas are shown in Figure 4.

A graph of the estimated household fuel demand and associated emissions for the two contrasting areas is shown in Figure 5. From this graph it can be seen that energy consumption and associated carbon emissions in the highly deprived area are just $57 \%$ of those in the contrasting area. In addition, when comparing with the UK mean, the energy use of the deprived area is $78 \%$ of the mean, whereas that of the contrasting area is $136 \%$ of the mean.

Comparing these results with those in Section 4.1 we can see that the differences between the results for these two specific Output Areas is less than the difference between the corresponding mean levels of the lowest and highest income deciles. To explain this we need to take a number of factors into account. First, the motivation for this part of the study is to demonstrate the highly geographically 
disaggregated nature of LARA. The two Output Areas were selected to be at extremes on the Index of Multiple Deprivation and, as explained in Section 3.4, this index is richer than a purely income based categorisation. Therefore, although one would expect these two specific Output Areas to be in the lowest and highest income deciles respectively, this is not necessarily the case. And even if they are in the lowest and highest income deciles, analysis of the distribution of household energy consumption within deciles has shown an extremely wide variation within each decile (Dresner and Ekins 2004; Roberts et al. 2007; Thumin et al. 2007). For example Dresner and Ekins (2004) found that households at the $80^{\text {th }}$ percentile of the lowest income decile consume nearly nine times as much energy as the households at the $20^{\text {th }}$ percentile of the same income decile, and more than twice as much energy as those at the $20^{\text {th }}$ percentile in the highest income decile. It is therefore not surprising that the variation in results shown in Figure 5 is less than the difference between the corresponding mean levels of the lowest and highest income deciles.

\subsection{OAC Supergroups}

In this section the mean household energy consumption and associated carbon emissions for each OAC Supergroup in England and Wales are presented and the results discussed. An analysis of the distribution of energy use and associated carbon emissions within OAC groups is beyond the remit of this paper. A summary of OAC Supergroup characteristics is shown in Appendix 2.

We first consider household expenditure on energy in relation to income for each Supergroup. Figure 6 shows normal weekly disposable income and the percentage of this that is spent on household energy for each OAC Supergroup. Households in Constrained by Circumstances have, as expected from the Supergroup name, on average, the lowest disposable income. These areas are dominated by social rented flats, with high proportions of single pensioner or lone parent households, and the head of the household is likely to be unemployed. Households in Constrained by Circumstances spend a higher percentage of disposable income on household fuel, on average, than those in other Supergroups. This is expected as, being the most deprived Supergroup, households in this Supergroup can be assumed to be in most danger of fuel poverty (Papathanasopoulou and Jackson 2007).

The households that spend the lowest proportion of disposable income on fuel are those in City Living, Prospering Suburbs and Typical Traits. These may be called "fuel rich" households, reflecting that the amount these households spend on fuel is not a significant factor in their weekly budget. The long run price elasticity of demand in the UK is inelastic, having been estimated at -0.22 by Hunt et al (2003) using structural time series modelling on quarterly unadjusted data from 1971q1 to 1997q4. It can be expected that the price elasticity of fuel rich households would be lower than that of the nation as a whole as their expenditure on household energy is a lower proportion of their total regular outgoings. Therefore these households may be considered even less likely than average to change their energy consumption in response to price increases. It is notable that the fuel rich households are not simply the affluent households in Prospering Suburbs (mean weekly disposable income £600), but include City Living and Typical Traits households (mean weekly disposable income of $£ 453$ and $£ 519$ respectively). This can be explained by City Living households being predominantly flats, which can be assumed to be fuel rich due to the thermal advantage that flats have compared to other types of dwellings. Typical Traits, as the name implies, is characterised by its closeness to the UK mean in terms of socio-demographic characteristics. This group has few values which are high or low in comparison with other Supergroups (Vickers et al. 2005). The categorisation of these households as fuel rich indicates that "average" households are generally well-off in fuel terms. Prospering Suburbs, the wealthiest Supergroup, have a high proportion of larger than average detached dwellings and a high proportion of $2+$ car households. The dwellings are predominantly owner occupied, and the owner is unlikely to be unemployed. Inclusion of this Supergroup in the fuel rich category is expected due to their comparatively high income levels.

Figure 7 shows estimated mean household energy consumption (all fuels), and associated carbon emissions, for each of the seven OAC Supergroups. The graph includes UK mean for comparison purposes. The picture for middle income households is not simply based on income. It shows that 
households in rural locations (Countryside) have much higher average energy use than those in urban locations (Multicultural and City Living). It also reflects that flats (of which there are high proportions in City Living and Multicultural) are more energy efficient than, for example, terraced housing (which is found in high proportions in Blue Collar Communities). Looking at the extremes of the income range, however, the results are in agreement with accepted understanding that energy use is related to income levels. Energy demand is highest in Prospering Suburbs, being 21\% higher than the UK mean, with associated carbon dioxide emissions $20 \%$ above UK mean. The lowest energy demand and carbon dioxide emissions occurs in Constrained by Circumstances (21\% below UK mean for energy and $20 \%$ for carbon dioxide emissions).

The pattern for electricity varies slightly from that for all fuels and gas, and the disparities are less pronounced. This reflects that the consumption of electricity for lighting and running appliances is less dependent on the type of dwelling and tenure of a household than the fuel required for space heating, which is not, in general, electricity. It also reflects that electricity is more strongly correlated with number of people per household, which is not directly captured by LARA (see Section 5). Graphs for household gas and electricity demand, with their associated carbon emissions are shown in Appendix 4.

City Living areas are interesting as they are characterised by a high proportion of flats, and also a high proportion of privately rented properties. As discussed in Section 2, flats are, in terms of space heating, relatively efficient, with lower heat loss than other types of dwelling (Shorrock and Utley 2003). On the other hand, privately rented accommodation is less likely to have good levels of loft insulation and other energy saving measures due to the landlord-tenant problem, as described in Section 2. Mean household electricity use in City Living areas is $9 \%$ below UK mean, whereas gas use is 18\% below mean (Figures 1 and 2, Appendix 4). This implies that the energy efficiency gained by being in a flat, on average, outweighs the general lack of energy efficient measures that tend to be put in place by private landlords.

The pattern differs substantially for Other Fuels. The numbers of households purchasing these fuels is smaller, and hence the uncertainties are higher. Therefore these results should be treated with a certain amount of caution. Other Fuel use is dominated, in terms of energy demand in kWh, by Oil for Central Heating and Coal. Urban demand for 'Other fuels' is hence expected to be small as urban areas are generally connected the main gas supply. The results support this hypothesis, with Countryside consuming the greatest quantity of Other Fuels (55\% above UK mean). A graph of these results is presented in Figure 3 in Appendix 4.

\section{Assumptions and limitations}

Household expenditure on fuels is recorded for a variety of different payment categories in the Expenditure and Food Survey (EFS), as shown in Table 2. Assumptions were required in order to match these categories to the more standard categories used in energy publications for the purposes of identifying prices and carbon emission factors. In a few cases in the EFS it is evident that electricity and gas payments were combined or mixed, and this may be a cause of errors. Some household cases in the sample recorded zero electricity payments which, on the face of it, is surprising. This is due to the method used to collect expenditure data in the EFS, and is compensated for by over-estimates in other values ${ }^{17}$. Furthermore, the small sample size of the EFS limits the accuracy of analysis in various ways. For example, estimation of expenditure on Other Fuels is limited in accuracy because these fuels are purchased by relatively few households. The ability of LARA to estimate material demand at high levels of socio-economic disaggregation is also limited by the sample size of the EFS. In particular, the sample sizes of minority socio-economic groups are small (Alexander et al. forthcoming).

The local area analysis in this study draws on data from Census 2001, as well as energy, price and expenditure data for the study year (2004-05). The Census is carried out at 10 year intervals, and 
therefore Census 2001 is the most recent such dataset. It is considered the most complete and reliable socio-economic dataset available in the UK, providing an incomparable depth of information with comprehensive geographical coverage (Vickers et al. 2005). Although some exceptional areas may change notably due to regeneration initiatives, it is assumed that the general socio-economic hierarchy of geographic areas is relatively static between 2001 and 2004-05 (Vickers et al. 2005).

It is important to remember that households do not purchase fuel for its own sake, but in order to access the services that fuel provides, such as a warm room or clean clothes (DTI 2007; Jackson 1996; Shove 2004). A limitation of this study is that it analyses fuel consumption and gives limited information about the service provided. For example, it does not give information on how much energy is used by different households for personal bathing and cooking, as these services may be provided by a combination of different fuels. Some information on this is available from the DTI Domestic Energy Consumption Tables ${ }^{18}$.

LARA was originally designed for estimation of general resource use, only one element of which is household energy use. On-going work involves use of LARA for modelling whole lifestyles, including energy use due to personal transportation and the energy embedded in goods and services purchased by households. The categorisation of Household Categories (HoCs, see Table 3) is therefore aimed at capturing expenditure with the greatest accuracy possible ${ }^{19}$. It would, in theory, be possible to re-define the basis of the $\mathrm{HoC}$ categorisation to optimise it for modelling household energy use. This may, for example, avoid merging HoCs across types of dwelling and tenure. In particular, it may be worth exploring the possibility of disaggregating social rented households into separate registered social landlord (RSL) and public rented sectors. Some factors that would ideally be included in categorising HoCs in LARA specifically for the purposes of modelling household energy consumption are urban/rural location, the age of dwelling and level of energy efficiency measures installed. However, to be used in this way, both factors are required to be present in the Expenditure and Food Survey (EFS) and the Census, and this criterion rules out use of these factors in LARA as it stands.

An alternative strategy would be to combine the work presented in this paper in some way with the information provided in the English House Condition Survey ${ }^{20}$, possibly along the lines used by Roberts et al (2007). Another possibility is that, at some stage in the future, the parts of the Expenditure and Food Survey that pertain to household energy use should be incorporated into the EHCS to achieve a single dataset that could then be used as the basis for energy efficiency policymaking and monitoring. In the meantime, to improve the usefulness of LARA for the purposes of targeting homes for energy efficiency improvements, results from LARA may be filtered using information on the age of dwelling stock and known energy efficiency measures already installed.

Household composition has been shown in this paper to be an influence on energy use, but is not a factor used directly in LARA. However, there is a correlation between Age of Representative Person and household composition and so it is indirectly accommodated. In future work results from LARA may be calculated on an per capita basis.

As discussed in Section 2, domestic energy use is dependent on lifestyles as well as technical factors. In this study differing lifestyles are captured inherently to a limited extent through the socio-economic variables used in LARA. A richer analysis may be obtained by using a commercial area segmentation system that includes lifestyle factors, as discussed in Section 3.5. Alternatively, results from LARA can be combined with empirical 'lifestyle' research: this is a subject of ongoing research by the RESOLVE group at the University of Surrey. ${ }^{21}$

\section{Conclusion}

In order to devise policies to move to a low carbon society, policy-makers need to understand the energy consumption of different types of households. In this paper we have explored UK household energy consumption and associated carbon dioxide emissions at three different levels for 2004-05. 
The first level is the national level. The other two levels make use of the highly disaggregated nature of the Local Area Resource Analysis (LARA) model to look at the mean household energy consumption in specific small geographical areas and that for "typical" types of households. To be more precise, we have presented results for specific neighbourhoods with contrasting levels of deprivation based on the Index of Multiple Deprivation, and for segments of UK households based on the UK National Output Area Classification. The results show that household fuel use and associated carbon emissions are both strongly, but not solely, related to income levels. Other factors, such as the type of dwelling, tenure, household composition and rural/urban location are also extremely important. We have illustrated that different segments of the population have very different energy consumptions depending their socio-economic characteristics.

The findings are of potential use to policy-makers in various ways. First, a targeted approach to the implementation of energy savings measures, such as energy efficiency advice and subsidies, has been found more likely to achieve socially acceptable results in an efficient and equitable manner. In theory LARA, possibly combined with information from the English House Condition Survey or with information concerning age of dwellings, can help in targeting: estimates from LARA of the quantities of gas, electricity and other fuels consumed by various types of households can be used to identify the types and geographic locations of households that may benefit from such interventions.

The study reported in this paper can be repeated for previous years in order to investigate trends. The trends can then be used as a basis for scenario building and hence as a basis for testing future policy options. One particular area of interest that is the subject for future research is the relationship between household energy consumption and the number of people per dwelling: in the paper we have demonstrated the economies of scale that can be achieved by larger households, and this has important policy implications in the light of the current trend of reduced household size.

The methodology described in this paper presents a useful method for testing the implications of possible policies, such as the introduction of personal carbon trading or a progressive tax regime on household energy. For example, by augmenting the price data used by LARA with progressive tax bands of, say, $0 \%$ for the first 3,000kWh p.a. of electricity use, $5 \%$ for the next $1,000 \mathrm{kWh}$ and $20 \%$ for demand beyond this, the effect of this tax regime on different types of households may be estimated. Testing along these lines is essential in order to avoid regressive policies, and is the subject of ongoing work.

The current price structure in the domestic fuel market tends to discriminate against low-income households, who generally pay more per unit of energy than higher income households (Moore 2005). This is, on the face of it, because these households are often unable or unwilling to choose payment methods such as direct debit, which attract lower tariffs. These low income households are not considered, in general, 'desirable' or 'favoured' customers in the eyes of suppliers due to factors such as their payment reliability and low average annual consumption (Roberts et al. 2007). This lack of 'desirability' is, to a certain extent, reflected in the higher tariffs charged by the suppliers to such customers $^{22}$. Under a cap-and-trade supplier obligation it is possible that low-energy low-income households may move from "less favoured" status to "more favoured" status (Roberts et al. 2007). Conversely, higher energy households, that are unable or unwilling to reduce energy consumption, may move to less favoured status. By using LARA to model the possible resulting changes in supplier price structures and specific reductions in customers' energy consumption, estimates can be made of the scheme's effect on different types of households in order to inform policy decisions ${ }^{23}$. For example, using LARA we can model the expected impacts for areas of extreme deprivation and affluence, and investigate the impacts on various socio-economic groups classified according to population segmentation systems such as the UK National Output Area Classification, as demonstrated in this paper, or commercial systems such as Acorn (CACI Ltd 2005) and Mosaic (Experian 2003).

Finally, the analysis described in this paper concerns just one facet of the mapping of energy lifestyles. In order to address energy reduction in a holistic manner, with the ability to take into 
account the rebound effect ${ }^{24}$, it is important to look at every aspect of energy use in people's lifestyles. This requires combining the household energy study in this paper with assessment of energy use for personal transportation and also with estimations of energy embedded in the goods and services consumed in the course everyday life. This wider study is the subject of on-going work.

In conclusion, in this paper we have explored patterns of UK household energy use and associated carbon emissions at the national level and using LARA, a highly socio-economically and geographically disaggregated model. We have discussed how LARA can be used to assess current trends in household energy use, to target energy efficiency initiatives, and to test the outcomes of possible policy options for achieving the transition to a low carbon society.

1 The study covers the year April 2004 to March 2005.

2 This is because the registered social landlord sector is a relatively new sector, comprising only $2.3 \%$ of households in 1981 rising to $10.3 \%$ in 2004. The age of the housing stock in the sector is relatively young: it has a small number of pre-1918 homes and a high proportion of 1972 homes. Newer dwellings are built to higher energy efficiency standards and this is the reason why dwellings in this sector have, on average, higher thermal insulation than other tenures (Shorrock and Utley 2003; Utley and Shorrock 2006).

${ }^{3}$ For the purposes of this document, 'gas' refers to metered gas.

${ }^{4}$ See http://www.cse.org.uk/

${ }^{5}$ See http://www.cse.org.uk/

${ }_{7}^{6}$ See http://www.dti.gov.uk/energy/statistics/publications/prices/index.html

${ }^{7}$ See http://www.sutherlandtables.co.uk/

${ }^{8}$ See http://www.energywatch.org.uk/

${ }^{9}$ See http://www.bre.co.uk/

${ }^{10}$ The total number of households in the UK is taken from the EFS 2004-05. This is an estimate only, as the true number of households is unknown, and measurements are only attempted every 10 years through the census.

${ }^{11}$ See Table 2.

${ }^{12}$ Each household has a designated Household Reference Person (HRP) who, for a person living alone is that person, or for more than one person, is chosen on the basis of their economic activity, followed by age (Office for National Statistics 2001).

${ }^{13}$ See http://www.statistics.gov.uk/ssd/surveys/expenditure_food_survey.asp

${ }^{14}$ As the energy structure is different in Northern Ireland from that in the rest of the UK (DSDNI 2004), the households representing N. Ireland in the EFS were omitted in the dataset that was used for the calculations in LARA.

${ }^{15}$ See Appendix 3 for details.

${ }^{16}$ Census 2001 Table UV56. http://neighbourhood.statistics.gov.uk

${ }^{17}$ The majority of households with zero electricity expenditure use the 'card, disc, token or electronic key' method for electricity payment. Expenditure using these methods is collected via the two-week diary and not the questionnaire, which covers three months (Dunstan 2007).

${ }^{18}$ See http://www.dti.gov.uk/energy/statistics/publications/ecuk/domestic/page18071.html

${ }^{19} \mathrm{~A}$ further explanation of the basis of the categories on which HoCs are designed is given in Druckman and Jackson (2007).

${ }^{20}$ The English House Condition Survey is a national survey of housing in England, commissioned by the Department for Communities and Local Government (Communities and Local Government). The survey involves a physical inspection of property by professional surveyors, and the information obtained through the survey is intended to provide an accurate picture of the type and condition of housing in England, the people living there, and their views on housing and their neighbourhoods (DCLG undated).

${ }^{21}$ http://www.surrey.ac.uk/resolve.

${ }^{22}$ It could be argued that tariffs applied to direct debit payments reflect the lower administrative cost.

${ }^{23}$ A study on this at the national level, using the national level dataset prepared for LARA, has already been carried out, see Roberts (2007).

${ }^{24}$ The rebound effect is said to occur when a technical or policy measure produces secondary effects that at least in part offset the initial, positive effect of the primary measure, so that the measure is less effective in achieving the primary goal (Hertwich 2006: page 101). 


\section{Acknowledgements}

The authors are grateful to the Centre for Sustainable Energy (in particular Joshua Thumim, Vicki White and Ian Preston) for provision of the fuel price matrix, and for the constructive discussions. We thank several anonymous referees for their helpful comments and suggestions. We are also grateful for funding from the ESRC Research Group on Lifestyles Values and Environment (RESOLVE) (Grant Number RES-152-25-1004) and EPSRC Sustainable Urban Environment Waste Consortium programme (Grant Number GR/S79626/01). Data from the 2001 Census are provided by the Commissioned Output Census Service of the Office for National Statistics (Crown Copyright 2005).

\section{References}

Alexander, C., A. Druckman, T. Jackson and C. Osinski (forthcoming). "Estimations of household material flows in deprived areas." Waste and Resource Management.

BERR. (2007). "The UK Fuel Poverty Strategy 5th Annual Progress Report." Accessed 06.03.08, from http://www.berr.gov.uk/files/file42720.pdf.

CACI Ltd (2005). ACORN: the smarter consumer classification. London, UK.

Carbon Trust (2006). The carbon emissions generated in all that we consume. London, UK, Carbon Trust.

Chambers, R. and H. Chandra (2006). Improved Direct Estimators for Small Areas: Methodology Working Paper M06/07, University of Southampton, UK.

DCLG. (undated). "English House Condition Survey (EHCS)." Accessed 03.03.08, from http://www.communities.gov.uk/housing/housingresearch/housingsurveys/englishhousecondit ion/.

Defra. (2005). "Guidelines for Company Reporting on Greenhouse Gas Emissions." 01.06.07, from http://www.defra.gov.uk/environment/business/envrp/gas/envrpgas-annexes.pdf.

Defra (2006). The Energy Efficiency Commitment. April 2008 to March 2011. Initial Consultation. London, UK, Department for Environment, Food and Rural Affairs.

Defra (2007a). Guidelines to Defra's GHG conversion factors for company reporting. Annexes updated June 2007. Defra, London, UK.

Defra. (2007b). "The Household Energy Supplier Obligation from 2011: A Call for Evidence." 28.02.08, from http://www.defra.gov.uk/environment/climatechange/uk/household/supplier/pdf/evidencecall.pdf.

Department for Communities and Local Government. (2006). "Review of the sustainability of existing buildings the energy efficiency of dwellings - initial analysis." Accessed 27.02.08, from http://www.communities.gov.uk/publications/planningandbuilding/reviewsustainability.

Department of Communities and Local Government. (2007). "Household estimates and projections: Great Britain, 1961-2026." Accessed 31.08.07, from http://www.communities.gov.uk/housing/housingresearch/housingstatistics/housingstatisticsb y/householdpopulation/. 
Department of Trade and Industry. (various years). "Digest of United Kingdom Energy Statistics (DUKES)." The Stationery Office, Accessed 19.03.06, from http://www.dti.gov.uk/energy/statistics/publications/dukes/page29812.html.

Dresner, S. and P. Ekins (2004). Economic Instruments for a Socially Neutral National Home Energy Efficiency Programme, Policy Studies Institute, London, UK.

Druckman, A., P. Sinclair and T. Jackson (2005). A geographically and socio-economically disaggregated local household consumption model for the UK. 10th European Roundtable on Sustainable Consumption and Production, Antwerp, Belgium, 5-7 October 2005.

Druckman, A. and T. Jackson (2007). The Local Area Resource Analysis (LARA) Model. Concepts, Methodology and Applications. . RESOLVE Working Paper 02-07, University of Surrey, Guildford, UK. Available from http://www.surrey.ac.uk/resolve/Docs/WorkingPapers/RESOLVE\%20WP\%2002-07.pdf.

Druckman, A., P. Sinclair and T. Jackson (2008). "A geographically and socio-economically disaggregated local household consumption model for the UK." Journal of Cleaner Production 16(7): 870-880.

DSDNI. (2004). "Ending Fuel Poverty:A Strategy for Northern Ireland." Accessed 270208, from http://www.dsdni.gov.uk/ending_fuel_poverty___a_strategy_for_ni.pdf.

DTI. (2005). "Quarterly Energy Prices. June 2005." Accessed 07.06.07, from http://www.dti.gov.uk/energy/statistics/publications/prices/index.html.

DTI. (2006). "Energy - its impact on environment and society ", Accessed 07/06/07, from http://www.dti.gov.uk/files/file32546.pdf.

DTI (2007). Meeting the Energy Challenge: A White Paper on Energy HM Government, London, UK

DTI. (various years). "Energy Trends ", Accessed 02.05.07, from http://www.dti.gov.uk/energy/statistics/publications/trends/index.html.

Dunstan, S. (2007). Personal email communication 18.05.07. London, Office for National Statistics.

Experian (2003). Mosaic United Kingdom: The Consumer Classification for the UK. Nottingham.

FPAG. (2006). "Fuel Poverty Advisory Group (for England) Fifth Annual Report." Accessed 06.03.08, from http://www.berr.gov.uk/files/file38873.pdf.

Heady, P., P. Clarke, G. Brown, K. Ellis, D. Heasman, S. Hennell, J. Longhurst and B. Mitchell (2003). Model-Based Small Area Estimation Series No. 2 Small Area Estimation Project Report. London, UK, Office for National Statistics.

Hertwich, E. (2006). Accounting for sustainable consumption: A review of studies of the environmental impacts of households In: The Earthscan Reader in Sustainable Consumption. T. Jackson.(Ed(s)) London, UK and Sterling, VA, USA, Earthscan.

HM Government (2006). UK Climate Change Programme 2006. London, UK, The Stationery Office.

Hunt, L. C., G. Judge and Y. Ninomiya (2003). "Underlying trends and seasonality in UK energy demand: a sectoral analysis." Energy Economics 25(1): 93. 
IPCC. (1997). "Revised 1996 IPCC Guidelines for National Greenhouse Gas Inventories. Volume 2: Workbook." Accessed January 2006, from http://www.ipccnggip.iges.or.jp/public/gl/guidelin/ch1wb1.pdf.

Jackson, T. (1992). Efficiency without Tears: towards a 'no-regrets' greenhouse policy. London, UK, Friends of the Earth.

Jackson, T. (1996). Material Concerns. Pollution, profit and quality of life, Routledge, London, UK.

Jackson, T. (2005). Lifestyle Change and Market Transformation: A briefing paper prepared for DEFRA’s Market Transformation Programme. London, Defra.

Jackson, T., E. Papathanasopoulou, P. Bradley and A. Druckman (2006). Attributing Carbon Emissions to Functional Household Needs: a pilot framework for the UK. International Conference on Regional and Urban Modelling, Brussels, Belgium. 1-2 June 2006.

Jackson, T., E. Papathanasopoulou, P. Bradley and A. Druckman (2007). Attributing UK Carbon Emissions to Functional Consumer Needs: methodology and pilot results. RESOLVE Working Paper 01-07, University of Surrey. Available from http://www.surrey.ac.uk/resolve/PDFs/RESOLVE\%20WP\%2001-07.pdf

Jackson, T. (2008). Sustainable Consumption and Lifestyle Change. In Lewis, A, (ed) Cambridge Handbook of Economic Psychology. Cambridge, UK: Cambridge University Press, 335-362. .

Lees, E. W. (2006). Evaluation of the Energy Efficiency Commitment 2002-05. Report to Defra, Eoin Lees Energy, Wantage, Oxon, UK.

Moore, R. (2005). "The Fall and Rise of Fuel Prices and Fuel Poverty." Accessed 10.08/07, from http://www.nea.org.uk/downloads/publications/The_Fall_and_Rise_of_Fuel_Prices_and_Fuel _Poverty_(FULL_REP).pdf.

Office for National Statistics. (2001). "Census 2001." Accessed 24.04.06, from http://www.statistics.gov.uk/census2001/pdfs/glossary.pdf.

Office for National Statistics. (2005). "Area classification for Output Areas ", Accessed 02.06.07, from http://www.statistics.gov.uk/about/methodology by theme/area_classification/oa/default.asp.

Office for National Statistics. (2006). "Geography Policy." Accessed 24.04.06, from http://www.statistics.gov.uk/geography/census geog.asp\#oa.

Office for National Statistics (2007). Social Trends, Palgrave Macmillan, Hampshire, UK.

Office for National Statistics (Various years). Family Spending: A report on the Expenditure and Food Survey. Basingstoke, Hampshire, UK.

Office for National Statistics and Department for Environment Food and Rural Affairs (2004-2005). Expenditure and Food Survey [computer file]. Colchester, Essex: UK Data Archive [distributor], February 2006. SN: 5375. .

Office of the Deputy Prime Minister (2004). The Indices of Deprivation 2004 London, UK.

Office of the Deputy Prime Minister. (2005). "Indices of deprivation 2004 - summary (revised)." Accessed 03.03.08, from http://www.communities.gov.uk/documents/communities/pdf/131206. 
Oxera. (2006). "Policies for energy efficiency in the UK household sector." Accessed 07.06.07, from http://www.defra.gov.uk/environment/energy/eeir/pdf/oxera-report.pdf.

Papathanasopoulou, E. and T. Jackson (2007). "Measuring Fossil Resource Inequality - a longitudinal case study for the UK: 1968-2000." Ecological Economics (submitted).

Pout, C. H. (2001). CO2 Emission Figures for Policy Analysis, BRE, Watford, UK.

Preston, I. (2007). Methodological Note on Fuel Prices Look-up Table. Bristol, UK, Centre for Sustainable Energy.

Rao, J. N. K. (2003). Small Area Estimation Hoboken, New Jersey, USA, Wiley-Interscience.

RCEP (2000). Energy - The Changing Climate. London, UK, Royal Commission on Environmental Pollution.

Roberts, S., V. White, I. Preston and J. Thumin (2007). Assessing the Social Impacts of a Supplier Obligation: A study for Defra. Bristol, UK, Centre for Sustainable Energy, Bristol, UK.

Shorrock, L. D. and J. I. Utley (2003). Domestic energy fact file 2003. London, UK, BRE, Defra and EST.

Shove, E. (2004). "Efficiency and Consumption: Technology and Practice." Energy and Environment 6: 1053.

Thumin, J., V. White, Z. Redgrove and S. Roberts (2007). Waste Not, Want Not: Energy Tariffs for Sustainability, WWF, Godalming, UK and Centre for Sustainable Energy, Bristol, UK.

Utley, J. I. and L. D. Shorrock (2006). Domestic energy fact file 2006. London, UK, BRE, Defra and EST.

Vickers, D., P. Rees and M. Birkin (2005). Creating the National Classification of Census Output Areas: Data, Method and Results, University of Leeds, UK.

Vickers, D. and P. Rees (2007). "Creating the UK National Statistics 2001 output area classification " Journal of the Royal Statistical Society: Series A (Statistics in Society) 179(2): 379.

Wilkinson, S. and C. Goodacre (2002). "Promoting energy efficiency in the private rented sector." Property Management 20(1): 49-63. 


\section{Appendix 1. Regional Weights}

Regional weighting value

Government Office Region

Number in
sample $(\mathrm{N})$

Fuel

consumption (all fuels)

CO2 due to fuel consumption (all fuels)

East Midlands
Eastern
London
North East
North West \& Merseyside
Northern Ireland
Scotland
South East
South West
Wales
West Midlands
Yorkshire and the Humber
Total (UK)

$\begin{array}{rll}1,709 & 1.02 & 1.02 \\ 2,274 & 1.00 & 1.02 \\ 2,908 & 0.96 & 0.94 \\ 1,023 & 1.01 & 1.01 \\ 2,673 & 1.04 & 1.00 \\ 654 & 1.03 & 1.18 \\ 2,152 & 0.97 & 0.96 \\ 3,524 & 0.99 & 0.99 \\ 2,144 & 0.88 & 0.91 \\ 1,203 & 1.09 & 1.08 \\ 2,165 & 1.01 & 1.00 \\ 1,989 & 1.09 & 1.09\end{array}$

24,418 


\section{Appendix 2. Selected characteristics of OAC Supergroups}

\begin{tabular}{|c|c|c|c|c|c|c|c|}
\hline & $\begin{array}{l}\text { Blue Collar } \\
\text { Communities }\end{array}$ & City Living & Countryside & Prospering Suburbs & $\begin{array}{l}\text { Constrained by } \\
\text { Circumstances }\end{array}$ & Typical Traits & Multicultural \\
\hline $\begin{array}{l}\text { Variables } \\
\text { distinctively } \\
\text { above national } \\
\text { average }\end{array}$ & $\begin{array}{ll}\text { - } & \text { Age 5-14 } \\
\text { - } & \text { Rent (public) } \\
\text { - } & \text { Terraced housing } \\
\text { - } & \text { Lone parent } \\
& \text { households }\end{array}$ & $\begin{array}{ll}\text { - } & \text { Age 25-44 } \\
\text { - } & \text { Population } \\
& \text { density } \\
\text { - } & \text { Rent (private) } \\
\text { - } & \text { Flats } \\
\text { - } & \text { No central } \\
& \text { heating }\end{array}$ & $\begin{array}{ll}\text { - } & \text { Age } 45+ \\
\text { - } & \text { Detached housing } \\
\text { - } & \text { Rooms per } \\
& \text { household } \\
\text { - } & 2+\text { car households }\end{array}$ & $\begin{array}{ll}\text { - } & \text { Age } 45-64 \\
\text { - } & \text { Detached housing } \\
\text { - } & \text { Rooms per } \\
\text { - } & \text { household } \\
\text { - } & \text { Two adults households } \\
& \text { children } \\
\text { - } & \text { Households with } \\
& \text { non-dependant } \\
& \text { children }\end{array}$ & $\begin{array}{l}\text { - } \text { Age 65+ } \\
\text { - } \quad \text { Single pensioner } \\
\text { households } \\
\text { - } \text { Rent (Public) } \\
\text { - Flats } \\
\text { - People room } \\
\text { - Unemployment }\end{array}$ & $\begin{array}{l}\text { Typical traits is } \\
\text { characterised by its } \\
\text { 'averageness'. This } \\
\text { Supergroup has few } \\
\text { values which are } \\
\text { high or low in } \\
\text { comparison to the } \\
\text { other groups. }\end{array}$ & $\begin{array}{l}\text { - } \text { Age 0-15 } \\
\text { - } \text { Born outside UK } \\
\text { - Population density } \\
\text { - No central heating } \\
\text { - People per room } \\
\text { - } \text { Flats } \\
\text { - Unemployment } \\
\text { - } \quad \text { Rent (public and } \\
\quad \text { private) }\end{array}$ \\
\hline $\begin{array}{l}\text { Variables } \\
\text { distinctively } \\
\text { below } \\
\text { national average }\end{array}$ & $\begin{array}{ll}\text { - } & \text { Rent (private) } \\
\text { - } & \text { Flats }\end{array}$ & $\begin{array}{lc}- & \text { Ages } 0-14 \\
- & \text { Rooms per } \\
& \text { household }\end{array}$ & $\begin{array}{ll}\text { - } & \text { Population density } \\
\text { - } & \text { Flats } \\
\text { - } & \text { People per room } \\
\text { - } & \text { Single person } \\
& \text { household }\end{array}$ & 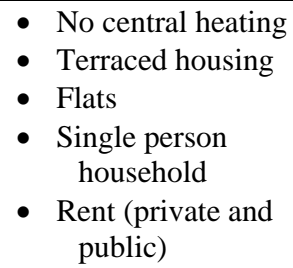 & $\begin{array}{ll}\text { - } & \text { Two adults no } \\
& \text { children } \\
\text { - } & \text { Rent (private) } \\
\text { - } & \text { Detached housing } \\
\text { - } & \text { Rooms per } \\
& \text { household } \\
\text { - } & 2+\text { car household }\end{array}$ & & $\begin{array}{l}\text { - } \quad \text { Age } 45+ \\
\text { - } \quad \text { Single pensioner } \\
\text { households } \\
\text { - } \quad \text { Detached housing }\end{array}$ \\
\hline
\end{tabular}

Source: Vickers et al (2005) and Office for National Statistics (2005) 


\section{Appendix 3. Correlations - National Dataset}

\begin{tabular}{|c|c|c|c|c|c|c|c|c|c|c|c|}
\hline \multicolumn{12}{|c|}{ HOUSEHOLD ENERGY USE } \\
\hline & \multicolumn{5}{|c|}{ Total energy (kWh) } & \multicolumn{3}{|c|}{ Electricity $(\mathrm{kWh})$} & \multicolumn{3}{|c|}{ Gas (kWh) } \\
\hline & Mean & $\begin{array}{l}\text { Standard } \\
\text { deviation }\end{array}$ & $\begin{array}{r}\text { Significance } \\
\text { level (p) }\end{array}$ & $r$ & $\mathrm{r} 2$ & $\begin{array}{r}\text { Significance } \\
\text { level }(p)\end{array}$ & $\mathrm{r}$ & 12 & $\begin{array}{r}\text { Significance } \\
\text { level (p) }\end{array}$ & $\mathrm{r}$ & r2 \\
\hline $\begin{array}{l}\text { Disposable weekly } \\
\text { income }(E)\end{array}$ & 489 & 435 & 0.01 & 0.27 & 0.08 & 0.01 & 0.25 & 0.06 & 0.01 & 0.23 & 0.05 \\
\hline $\begin{array}{l}\text { Household } \\
\text { composition }\end{array}$ & 2.4 & 1.3 & 0.01 & 0.24 & 0.06 & 0.01 & 0.27 & 0.07 & 0.01 & 0.20 & 0.04 \\
\hline \multicolumn{12}{|c|}{ HOUSEHOLD CARBON DIOXIDE EMISSIONS } \\
\hline & & & $\begin{array}{r}\mathrm{CO} 2 \mathrm{du} \\
\text { Significance }\end{array}$ & use (c & & $\begin{array}{r}\mathrm{CO} 2 \\
\text { Significance }\end{array}$ & electricity & & Significance & to gas & \\
\hline & & & level (p) & $r$ & r2 & level (p) & $\mathrm{r}$ & r2 & level (p) & $\mathrm{r}$ & $\mathrm{r} 2$ \\
\hline $\begin{array}{l}\text { Disposable weekly } \\
\text { income }(£)\end{array}$ & & & 0.01 & 0.27 & 0.07 & 0.01 & 0.25 & 0.06 & 0.01 & 0.23 & 0.05 \\
\hline $\begin{array}{l}\text { Household } \\
\text { composition }\end{array}$ & & & 0.01 & 0.26 & 0.07 & 0.01 & 0.27 & 0.07 & 0.01 & 0.20 & 0.04 \\
\hline
\end{tabular}

\begin{tabular}{|c|c|c|c|c|c|c|c|c|c|}
\hline \multicolumn{10}{|c|}{ PER CAPITA ENERGY USE } \\
\hline & \multicolumn{3}{|c|}{ Total energy (kWh) } & \multicolumn{3}{|c|}{ Electricity (kWh) } & \multicolumn{3}{|c|}{ Gas (kWh) } \\
\hline & Significance & & & Significance & & & Significance & & \\
\hline & level $(p)$ & $r$ & 12 & level $(p)$ & $r$ & $\mathrm{r} 2$ & level $(p)$ & $\mathrm{r}$ & $\mathrm{r} 2$ \\
\hline $\begin{array}{l}\text { Household } \\
\text { composition }\end{array}$ & 0.01 & -0.33 & 0.11 & 0.01 & -0.37 & 0.14 & 0.01 & -0.29 & 0.08 \\
\hline \multicolumn{10}{|c|}{ PER CAPITA CARBON DIOXIDE EMISSIONS } \\
\hline & \multicolumn{3}{|c|}{$\mathrm{CO} 2$ due to fuel use (all fuels) } & \multicolumn{3}{|c|}{ CO2 due to electricity } & \multicolumn{3}{|c|}{$\mathrm{CO} 2$ due to gas } \\
\hline & $\begin{array}{r}\text { Significance } \\
\text { level }(p)\end{array}$ & $r$ & $\mathrm{r} 2$ & $\begin{array}{r}\text { Significance } \\
\text { level (p) }\end{array}$ & $\mathrm{r}$ & r2 & $\begin{array}{r}\text { Significance } \\
\text { level }(p)\end{array}$ & $\mathrm{r}$ & $\mathrm{r} 2$ \\
\hline $\begin{array}{l}\text { Household } \\
\text { composition }\end{array}$ & 0.01 & -0.36 & 0.13 & 0.01 & -0.37 & 0.14 & 0.01 & -0.29 & 0.08 \\
\hline
\end{tabular}


Appendix 4. Household energy consumption and associated carbon emissions for OAC Supergroups

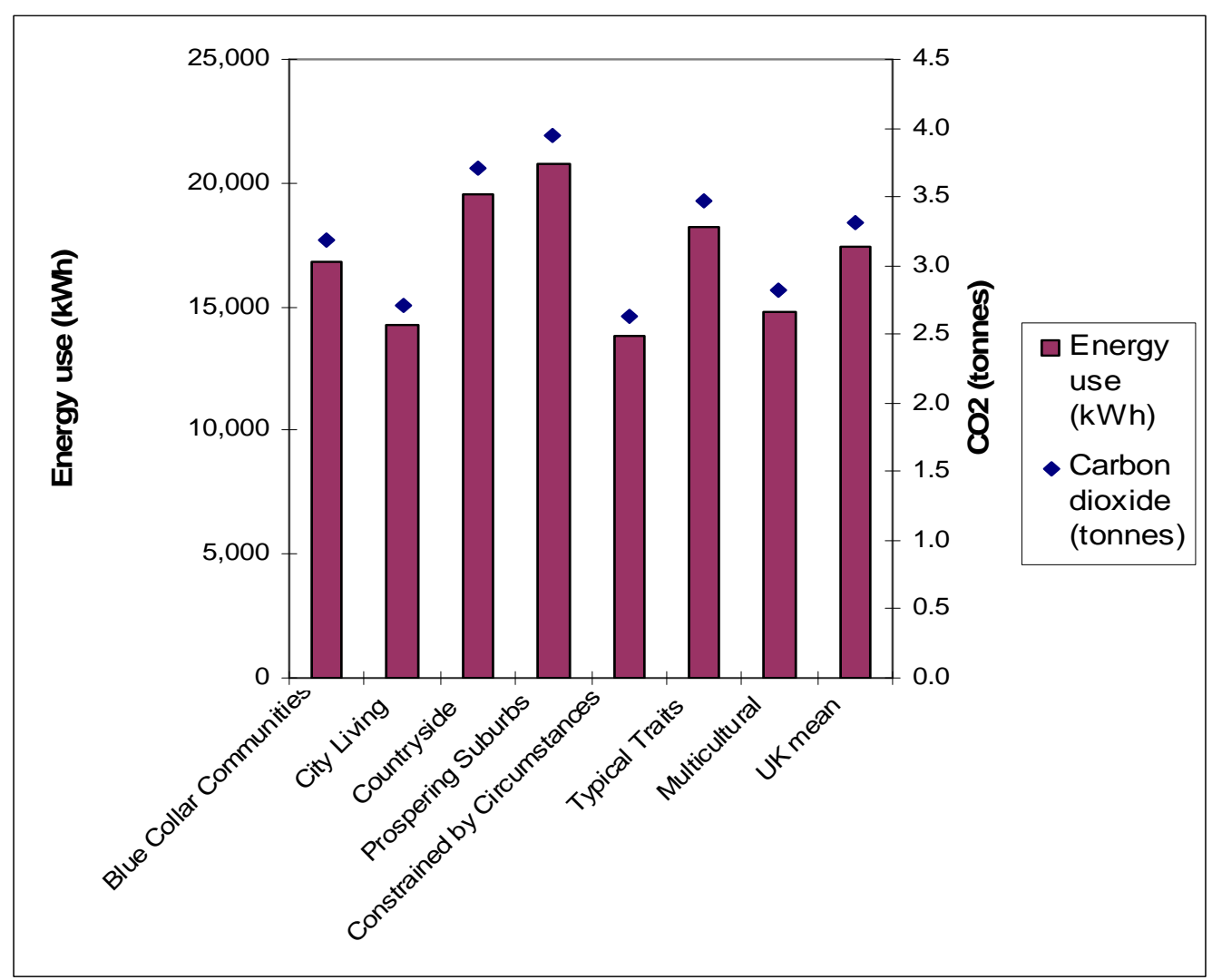

Figure A4.1. Annual mean household gas consumption and associated carbon dioxide emissions. 


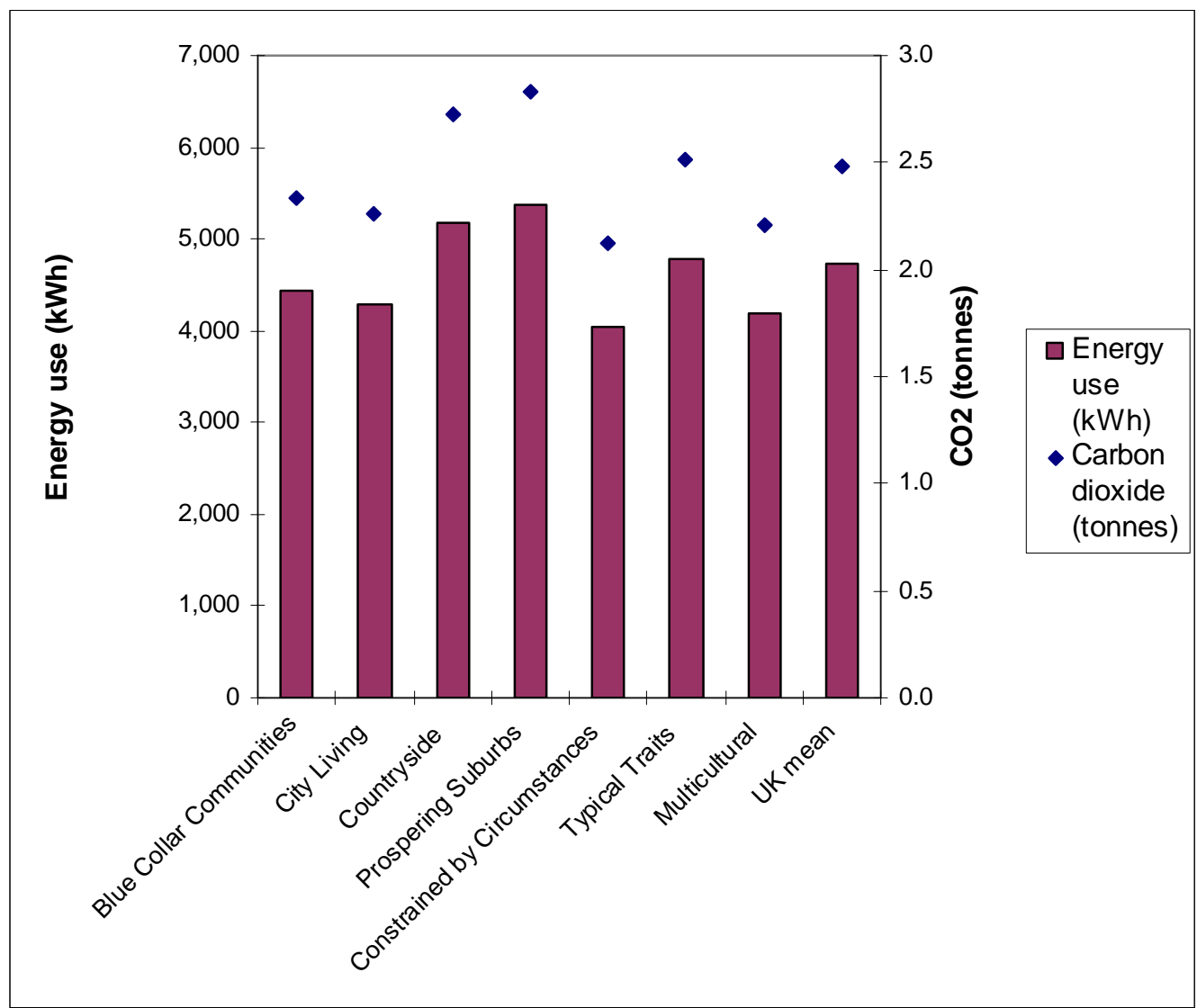

Figure A4.2. Annual mean household electricity consumption and associated carbon dioxide emissions. 


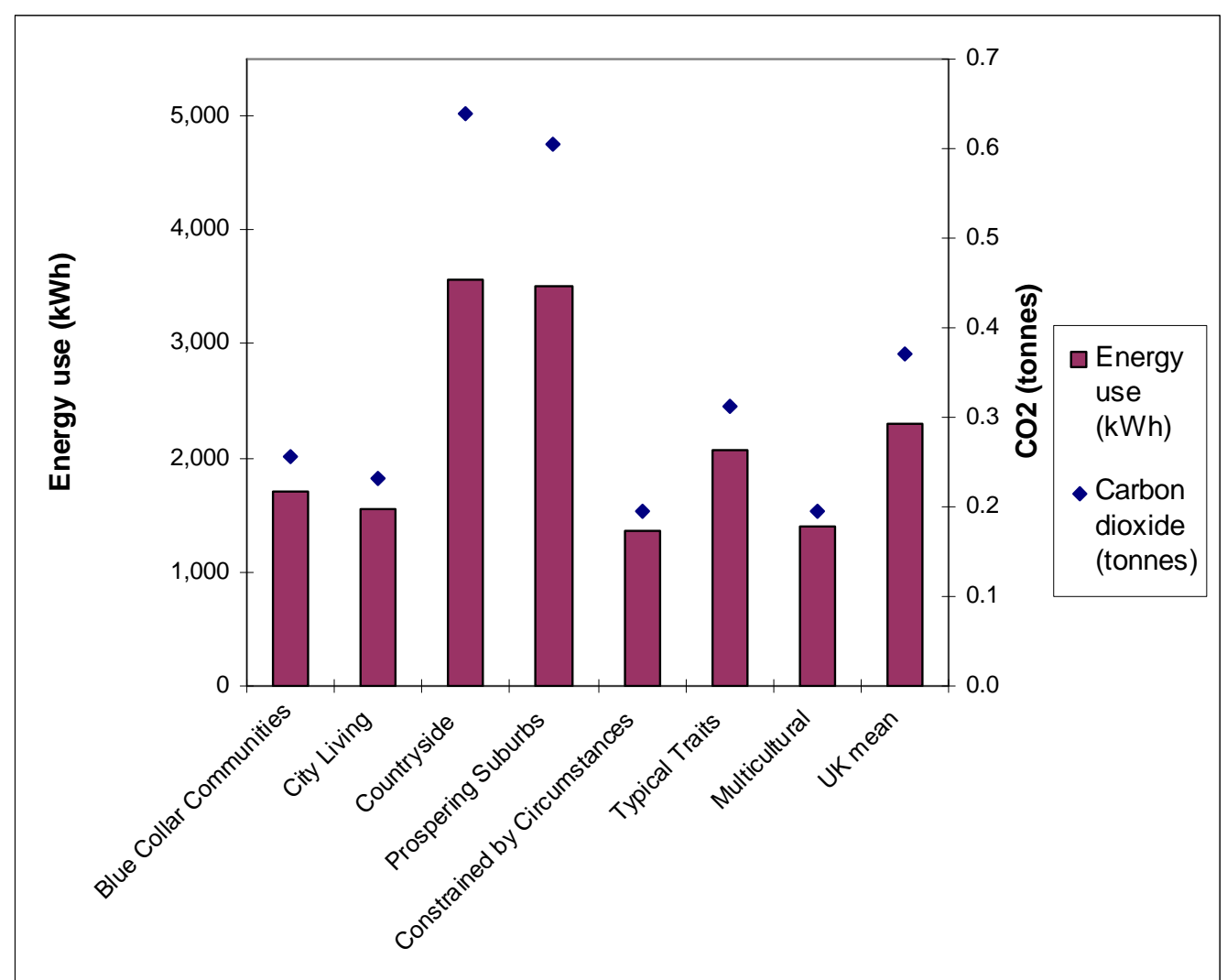

Figure A4.3. Annual mean household consumption of Other Fuels, and associated carbon dioxide emissions. 
Table 1. Typical average heat loss of dwelling types

Type of dwelling

Detached

Heat loss $\left(\mathrm{W} /{ }^{\circ} \mathrm{C}\right)$

Semi-detached

365

Terraced

276

Bungalow

243

Flat

229

UK mean

182

Source: Shorrock and Utley (2003: page 34) 
Table 2. Fuel categories and their carbon dioxide emissions factors

\begin{tabular}{|c|c|c|}
\hline Payment categories & Price categories & $\begin{array}{c}\text { Carbon dioxide emission factor }{ }^{\text {a }} \\
\text { (kg CO2 per kWh) }\end{array}$ \\
\hline $\begin{array}{l}\text { Electricity } \\
\text { Slot meter } \\
\text { Account } \\
\text { Board budget scheme } \\
\text { Second dwelling }\end{array}$ & $\begin{array}{l}\text { Electricity } \\
\text { Pre-payment } \\
\text { Credit } \\
\text { Direct debit } \\
\text { Credit }\end{array}$ & $0.526^{b}$ \\
\hline $\begin{array}{l}\text { Gas (metered) } \\
\text { Slot meter } \\
\text { Account } \\
\text { Board budget scheme } \\
\text { Second dwelling }\end{array}$ & $\begin{array}{c}\text { Gas (metered) } \\
\text { Pre-payment } \\
\text { Credit } \\
\text { Direct debit } \\
\text { Credit }\end{array}$ & 0.190 \\
\hline \multicolumn{3}{|l|}{ Other Fuels } \\
\hline Bottled gas for central heating & Bottle Gas Propane & 0.214 \\
\hline Bottled gas - other & Bulk LPG ${ }^{\mathrm{c}}$ & 0.214 \\
\hline Coal \& coke & Coal & 0.320 \\
\hline Oil for central heating & Heating oil & 0.245 \\
\hline Paraffin & Heating oil & $0.259^{\mathrm{d}}$ \\
\hline Wood \& peat & Wood & $0.025^{\mathrm{e}}$ \\
\hline
\end{tabular}

${ }^{a}$ Unless otherwise stated, the carbon dioxide emission factors are taken from Defra (2005).

${ }^{\mathrm{b}}$ The carbon dioxide emission intensity factor for electricity is based on total carbon due to electricity generation of 46.38mtC provided by AEA Energy \& Environment from the 2007 NAEI / UK Greenhouse Gas Inventory. Total electricity supply is taken generation the Digest of UK Energy Statistics 2006 (DUKES) Table 5.6 and losses are accounted for according to DUKES Table 5.2. DUKES is available from http://www.dti.gov.uk/energy/statistics/publications/dukes/page29812.html. The figure is very close to that of $0.527 \mathrm{~kg}$ CO2/kWh published by Defra (2007a).

${ }^{c}$ LPG is the generic name for commercial propane (http://www.lpga.co.uk/fr_ab_lp.htm)

d The carbon dioxide emission factor for Kerosene (or "Burning Oil”) is taken from IPCC (1997).

e This value is taken from Pout (2001). The non-zero value takes into account estimates of CO2 emissions from 'planting, harvesting, sawing up and other processing, and delivery to the point of use. The inclusion of transportation for renewable fuels is justified as they tend to be bulkier than fossil fuels, and as they are less widely used the distances travelled are likely to be larger' (Pout 2001: page 5). 
Table 3. Household Categories (HoCs)

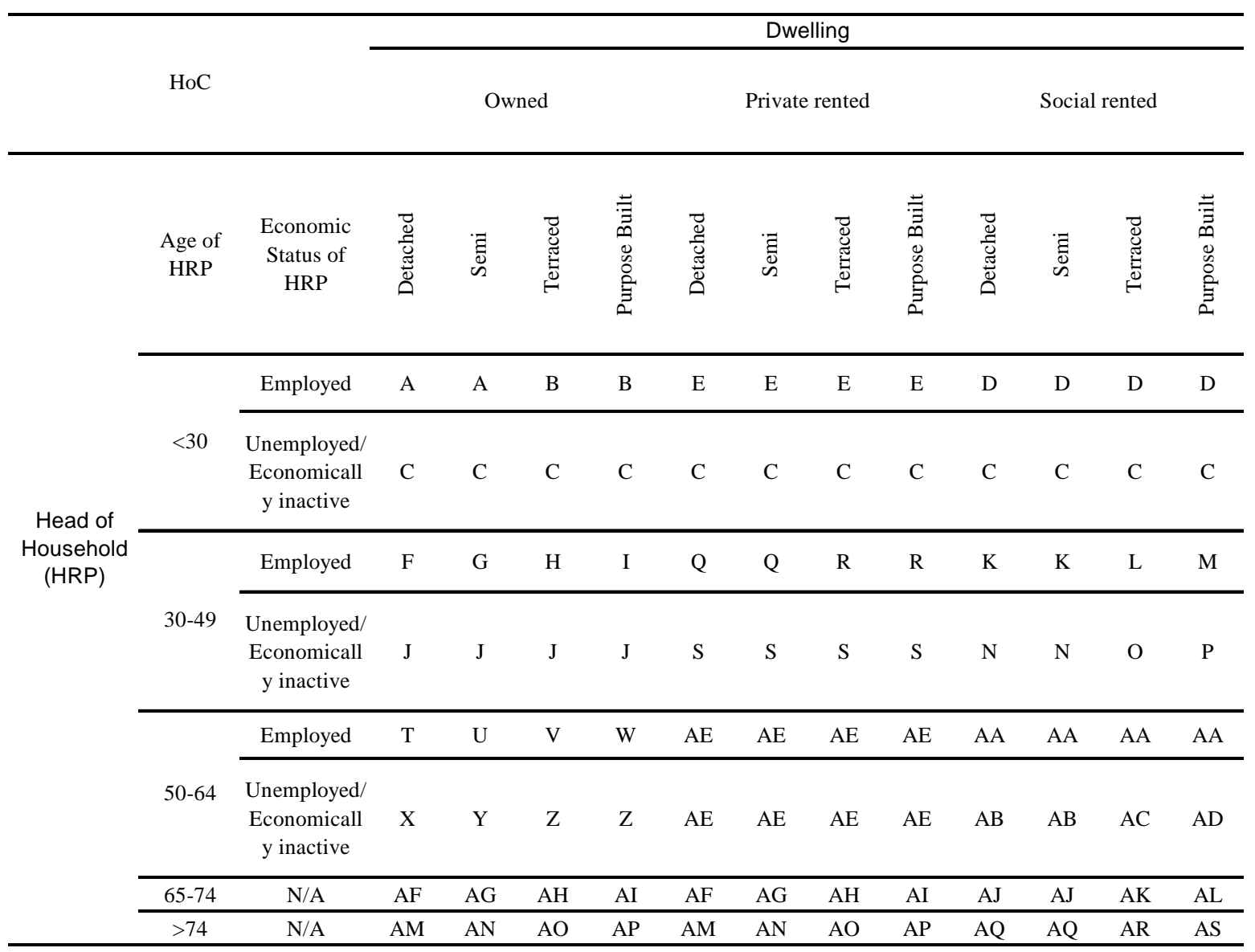

\section{Explanatory Notes}

Detached: Detached house or bungalow.

Semi: Semi-detached house or bungalow

Terraced: Terraced house or bungalow; flat, maisonette or apartment which is part of a converted or shared house; or in a commercial building.

Purpose Built: Purpose built flat, maisonette or apartment, caravan or other mobile structure.

Private Rented: Rented, private or rent free.

Social Rented: Rented, from council or Registered Social Landlord or Housing Association.

Employed: Full-time/part-time employee or self employed. 


\section{Captions to illustrations}

\begin{tabular}{|c|l|}
\hline Figure & Caption \\
\hline 1 & LARA system diagram \\
\hline $2 \mathrm{a}$ & Mean annual household energy use by disposable income decile. \\
\hline $2 \mathrm{~b}$ & $\begin{array}{l}\text { Mean annual household carbon dioxide emissions due to energy use by disposable } \\
\text { income decile. }\end{array}$ \\
\hline 3 & $\begin{array}{l}\text { Expenditure on energy as a percentage of disposable income for disposable income } \\
\text { deciles. }\end{array}$ \\
\hline 4 & $\begin{array}{l}\text { Case study areas representing extremes of deprivation and affluence. } \\
\text { Source: ONS http://neighbourhood.statistics.gov.uk }\end{array}$ \\
\hline 5 & $\begin{array}{l}\text { Mean annual household energy consumption and associated carbon dioxide emissions } \\
\text { for specific Output Areas representing extremes of deprivation and affluence }\end{array}$ \\
\hline 6 & $\begin{array}{l}\text { Normal weekly disposable income and the percentage spent on energy for OAC } \\
\text { Supergroups }\end{array}$ \\
\hline 7 & $\begin{array}{l}\text { Mean annual household energy use and associated carbon dioxide emissions (all fuels) } \\
\text { for OAC Supergroups }\end{array}$ \\
\hline
\end{tabular}

\section{Captions to illustrations in Appendix 4}

\begin{tabular}{|c|l|}
\hline Figure & Caption \\
\hline A4.1 & Annual mean household gas consumption and associated carbon dioxide emissions. \\
\hline A4.2 & $\begin{array}{l}\text { Annual mean household electricity consumption and associated carbon dioxide } \\
\text { emissions. }\end{array}$ \\
\hline A4.3 & $\begin{array}{l}\text { Annual mean household consumption of Other Fuels, and associated carbon dioxide } \\
\text { emissions. }\end{array}$ \\
\hline
\end{tabular}




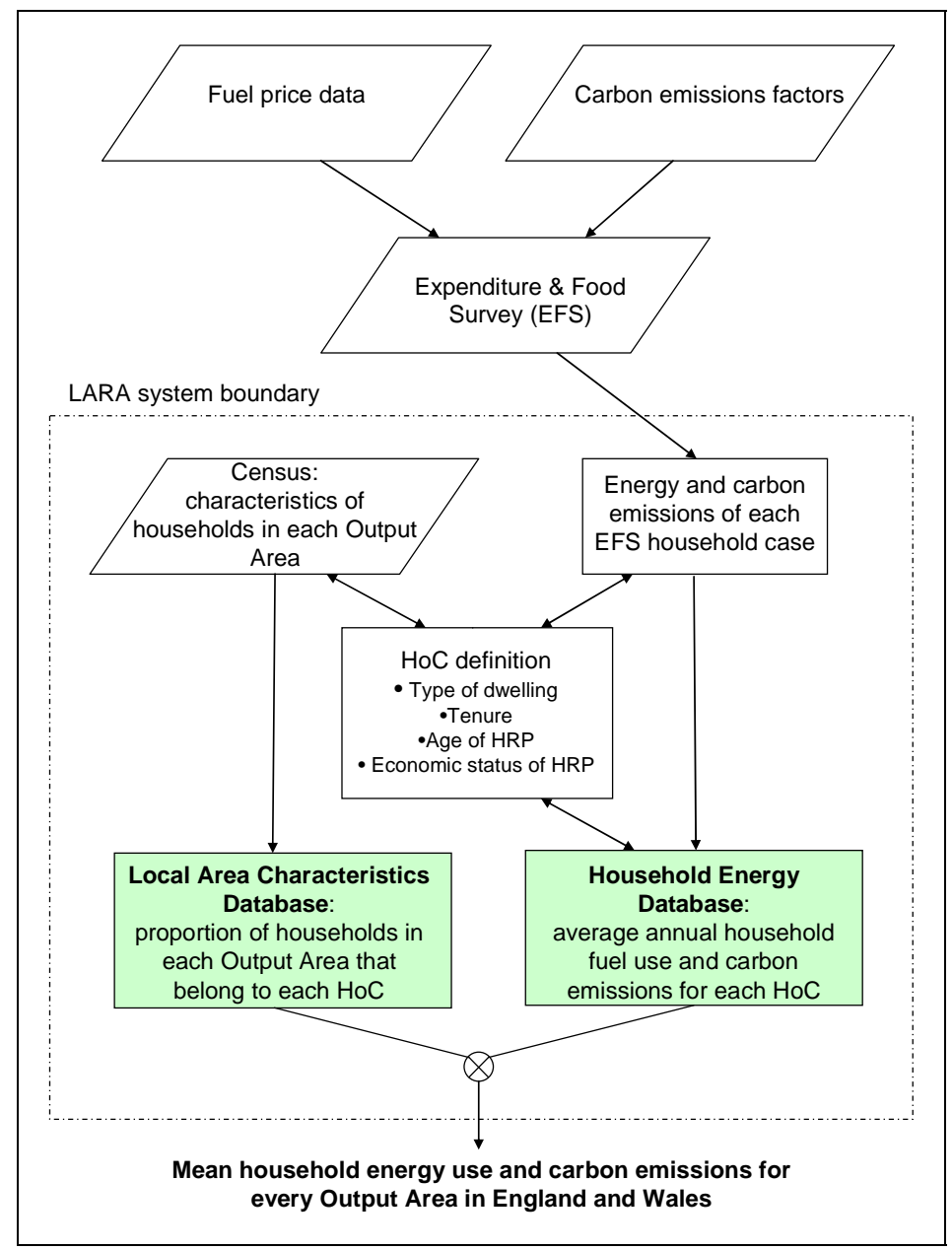

Figure 1. LARA system diagram 


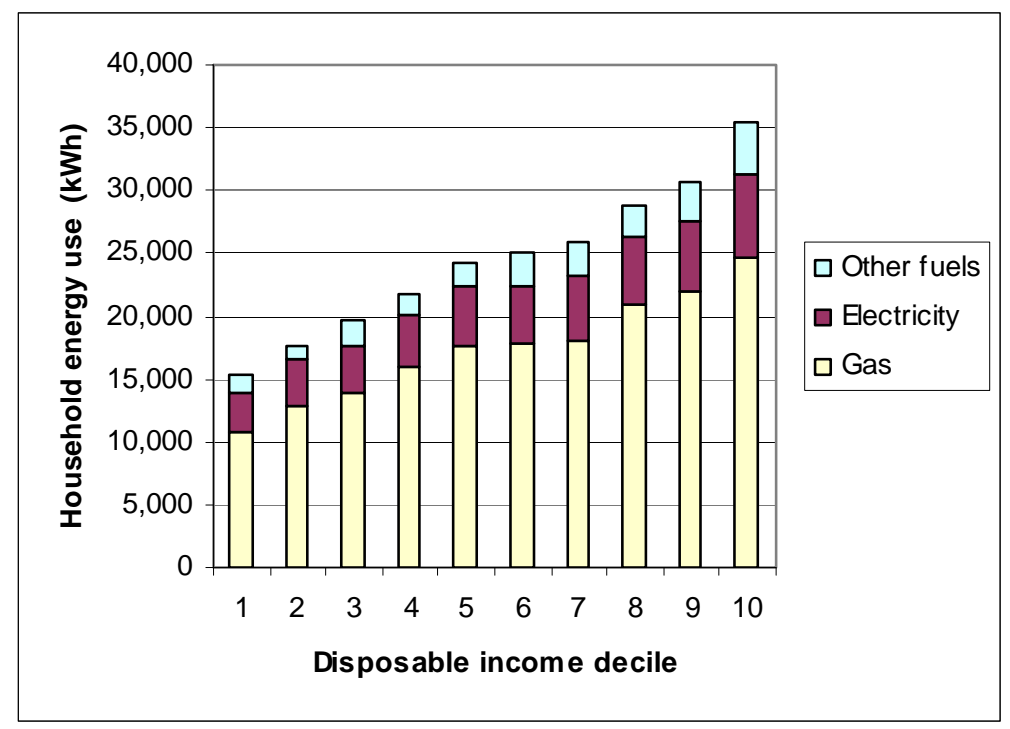

Figure 2a. Mean annual household energy use by disposable income decile.

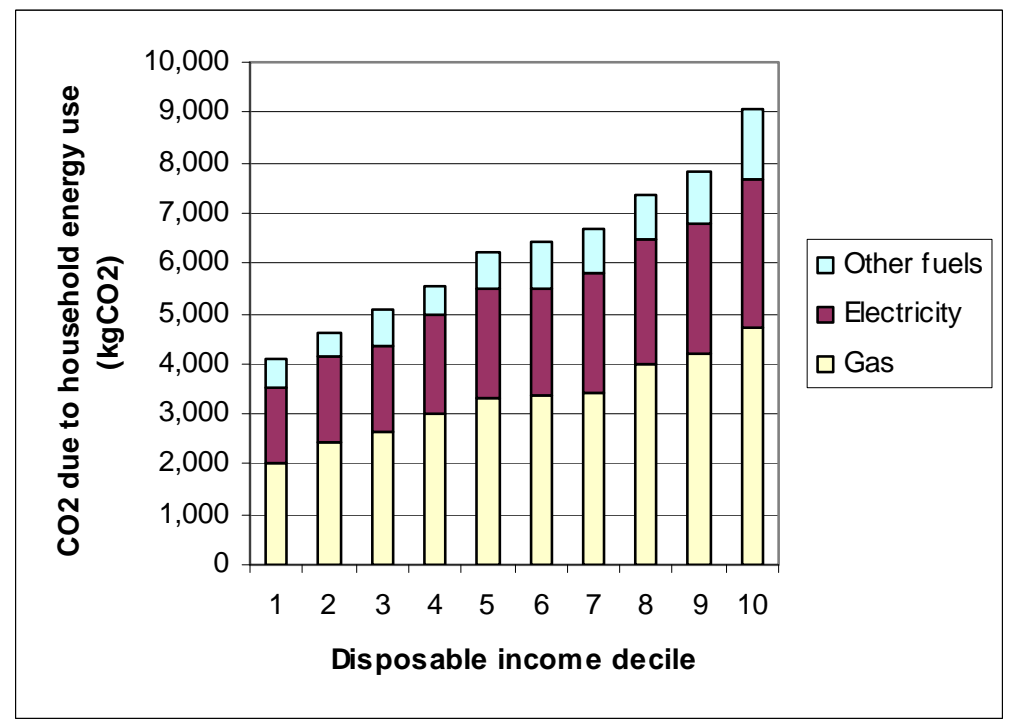

Figure 2b. Mean annual household carbon dioxide emissions due to energy use by disposable income decile. 


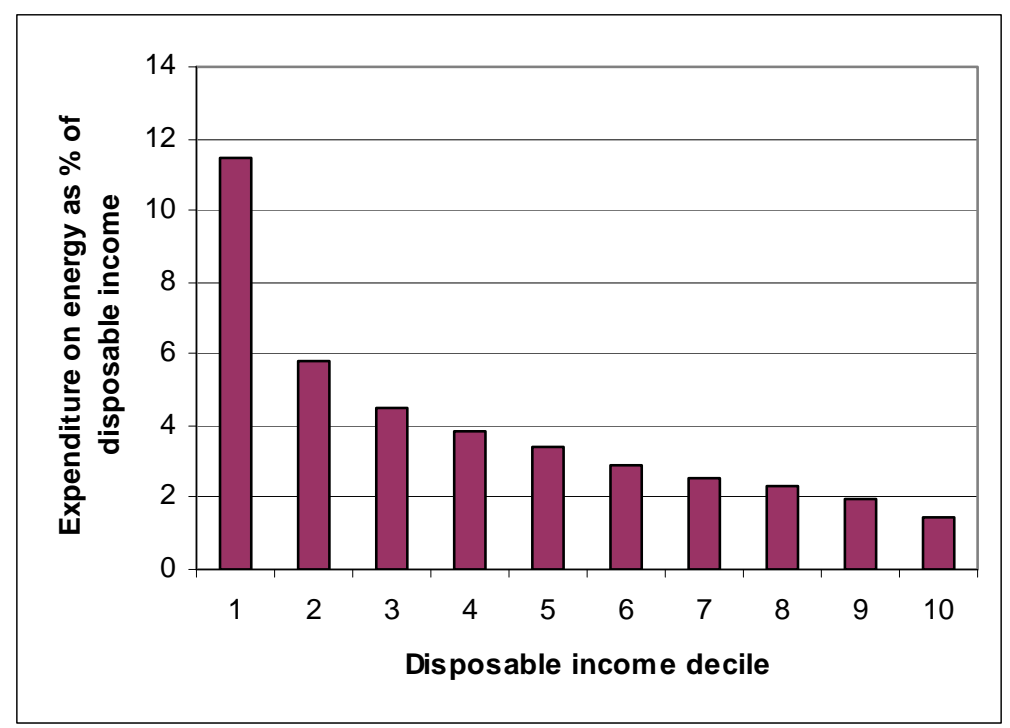

Figure 3. Expenditure on energy as a percentage of disposable income for disposable income deciles.

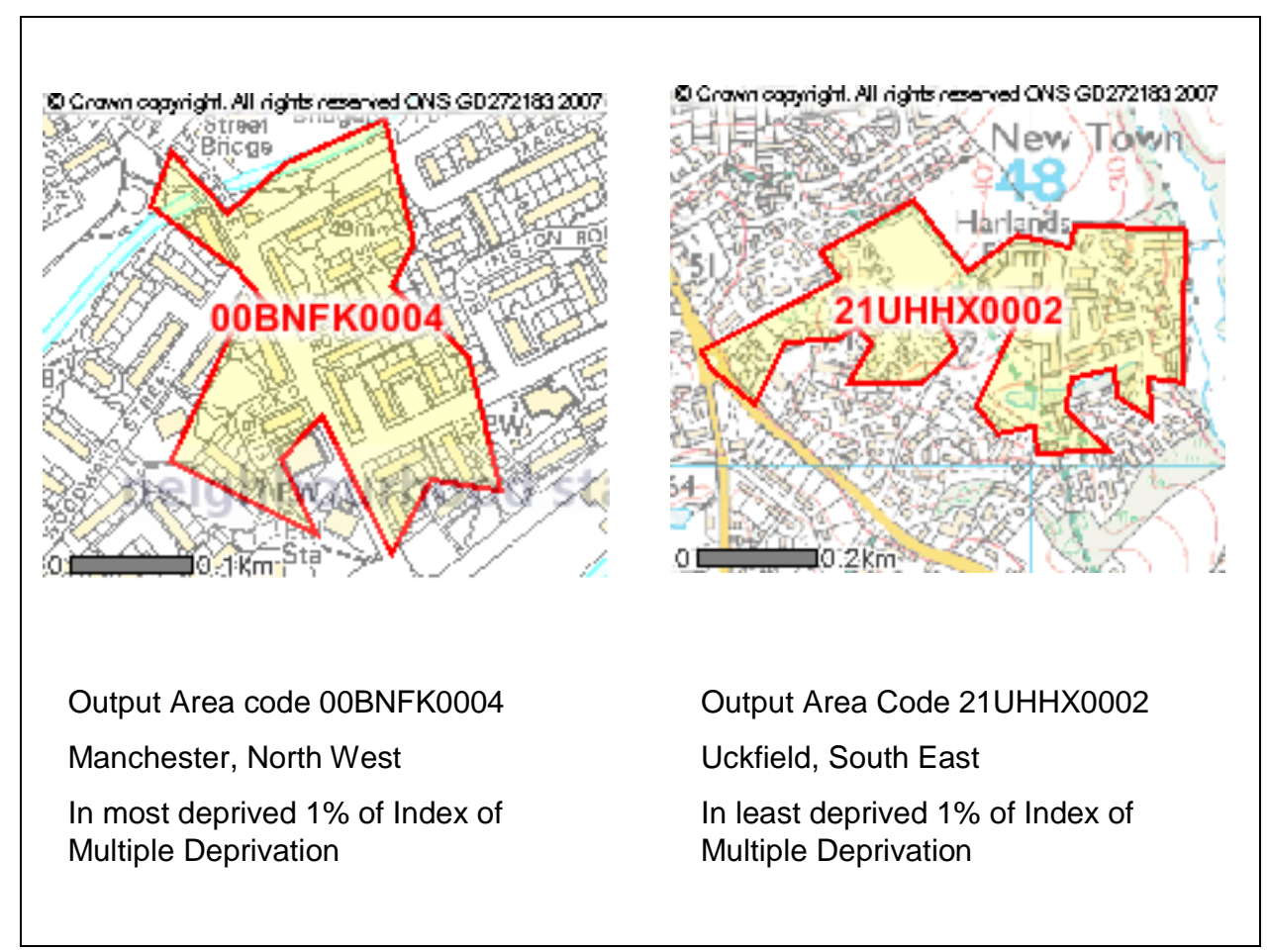

Figure 4. Case study areas representing extremes of deprivation and affluence. Source: ONS http://neighbourhood.statistics.gov.uk 


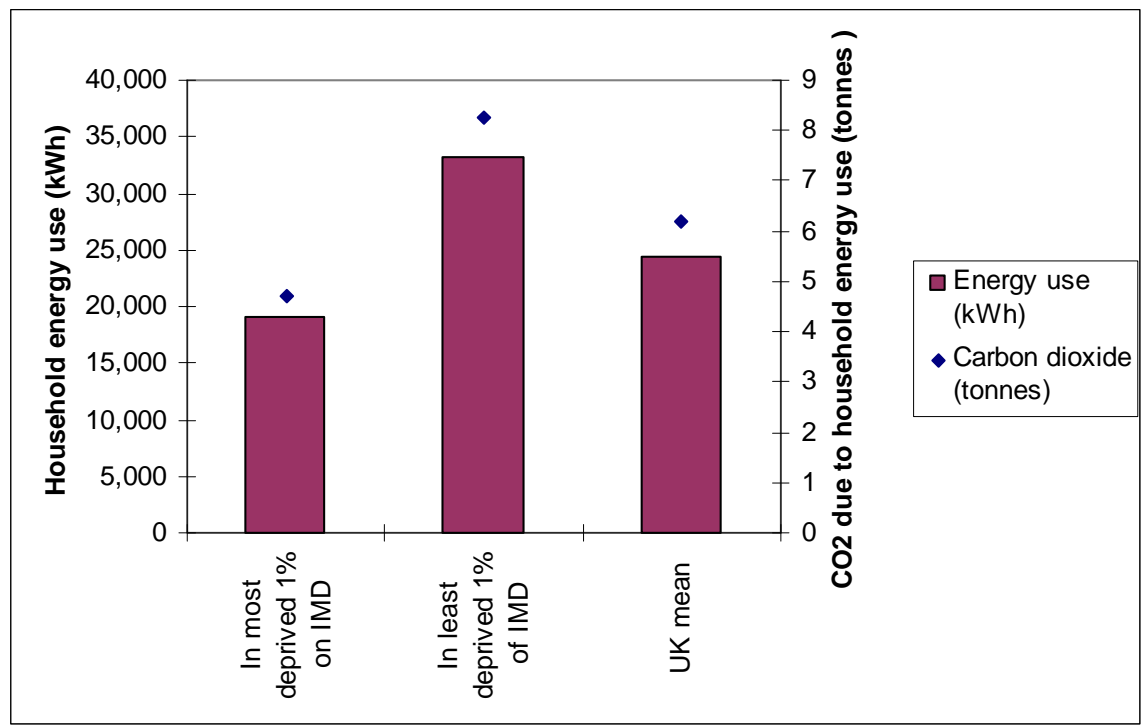

Figure 5. Mean annual household energy consumption and associated carbon dioxide emissions for specific Output Areas representing extremes of deprivation and affluence 


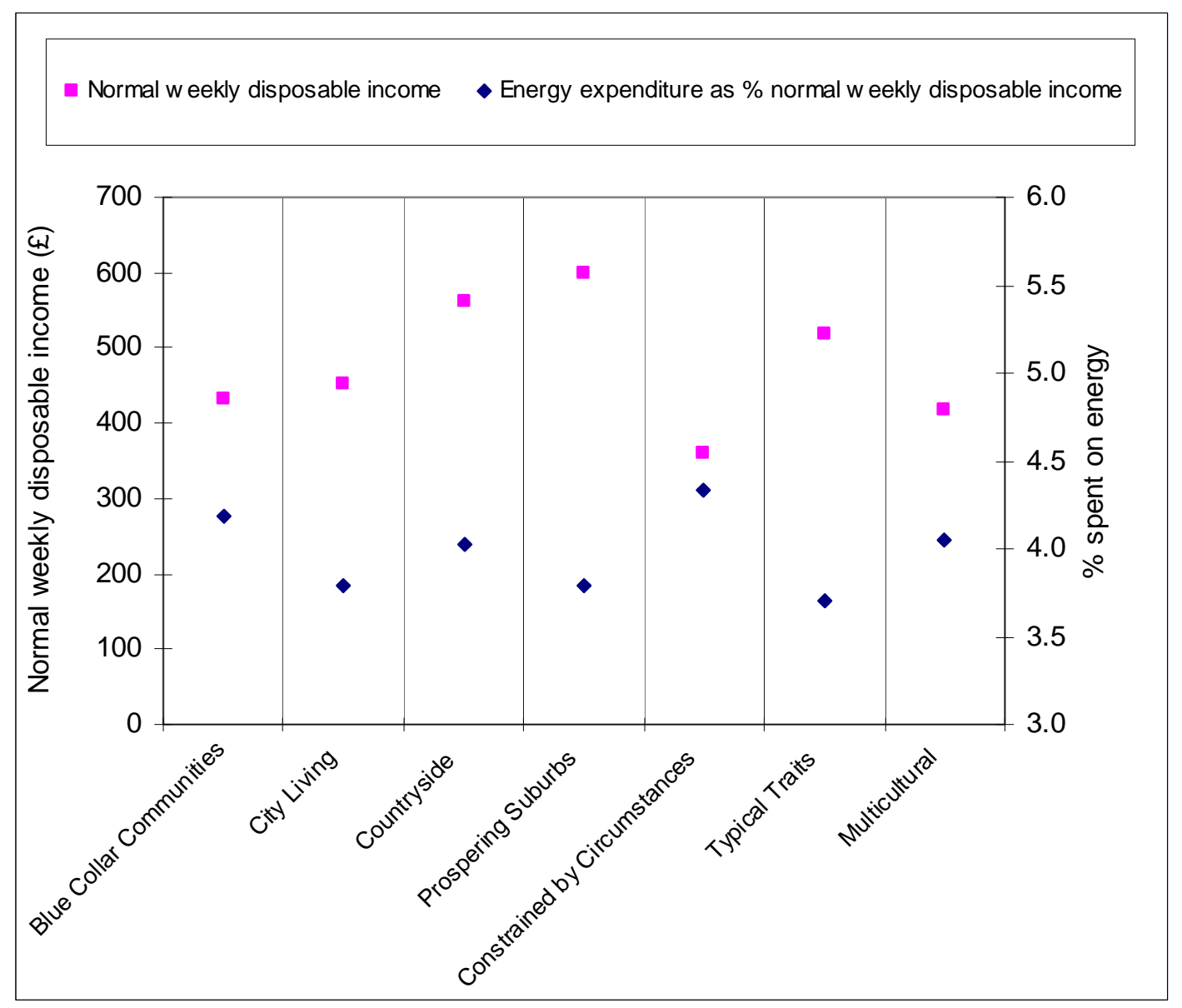

Figure 6. Normal weekly disposable income and the percentage spent on energy for OAC Supergroups 


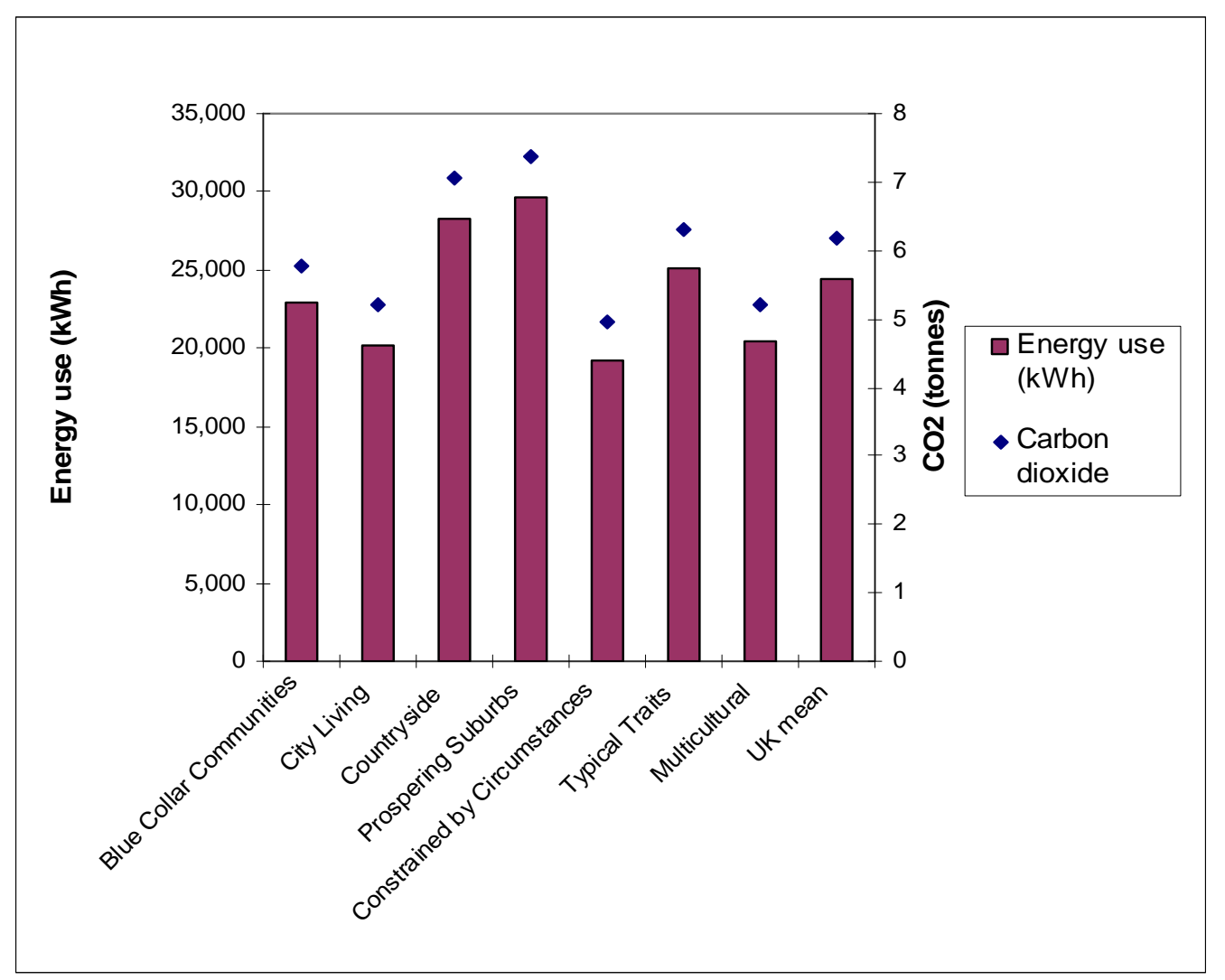

Figure 7. Mean annual household energy use and associated carbon dioxide emissions (all fuels) for OAC Supergroups 